\title{
The impact of Arctic sea ice on the Arctic energy budget and on the climate of the Northern mid-latitudes
}

\author{
Tido Semmler $\cdot$ Ray McGrath $\cdot$ Shiyu Wang
}

Received: 5 July 2011/ Accepted: 21 March 2012/Published online: 15 April 2012

(C) The Author(s) 2012. This article is published with open access at Springerlink.com

\begin{abstract}
The atmospheric general circulation model ECEARTH-IFS has been applied to investigate the influence of both a reduced and a removed Arctic sea ice cover on the Arctic energy budget and on the climate of the Northern mid-latitudes. Three 40-year simulations driven by original and modified ERA-40 sea surface temperatures and sea ice concentrations have been performed at T255L62 resolution, corresponding to $79 \mathrm{~km}$ horizontal resolution. Simulated changes between sensitivity and reference experiments are most pronounced over the Arctic itself where the reduced or removed sea ice leads to strongly increased upward heat and longwave radiation fluxes and precipitation in winter. In summer, the most pronounced change is the stronger absorption of shortwave radiation which is enhanced by optically thinner clouds. Averaged over the year and over the area north of $70^{\circ} \mathrm{N}$, the negative
\end{abstract}

This paper is a contribution to the special issue on EC-Earth, a global climate and earth system model based on the seasonal forecast system of the European Centre for Medium-Range Weather Forecasts, and developed by the international EC-Earth consortium. This special issue is coordinated by Wilco Hazeleger (chair of the EC-Earth consortium) and Richard Bintanja.

T. Semmler $(\bowtie)$

Alfred Wegener Institute for Polar and Marine Research,

Am Handelshafen 12, 27570 Bremerhaven, Germany

e-mail: tido.semmler@awi.de

T. Semmler $\cdot$ R. McGrath $\cdot$ S. Wang

Met Éireann, Glasnevin Hill, Dublin 9, Ireland

e-mail: ray.mcgrath@met.ie

S. Wang

e-mail: shiyu.wang@smhi.ie

S. Wang

Swedish Meteorological and Hydrological Institute,

Folkborgsvägen 1, 60176 Norrköping, Sweden energy imbalance at the top of the atmosphere decreases by about $10 \mathrm{~W} / \mathrm{m}^{2}$ in both sensitivity experiments. The energy transport across $70^{\circ} \mathrm{N}$ is reduced. Changes are not restricted to the Arctic. Less extreme cold events and less precipitation are simulated in sub-Arctic and Northern midlatitude regions in winter.

\section{Introduction}

Arctic sea ice has been declining at an unprecedented rate over recent decades and faster than predicted by climate models whose results were included in the 4th Assessment Report of the Intergovernmental Panel on Climate Change (IPCC 2007; Stroeve et al. 2007; Budikova 2009). The Arctic could be icefree in late summer by the middle of this century or even earlier (Serreze et al. 2007a). In 2007, a record low Arctic sea ice coverage was recorded in a multi-decadal trend towards thinner sea ice, and multi-year sea ice is being increasingly replaced by 1-year sea-ice, which is more prone to melting (Lindsay et al. 2009). Since these changes can have impacts on the climate well beyond the Arctic it is important to further study the role of the Arctic sea ice in the climate system.

In previous studies using ocean models and observation data it has been argued that changes in the high-latitude sea surface temperature (SST) and sea ice concentration (SIC) are largely affected by atmospheric changes in the highand mid-latitudes (e.g. Seager et al. 2000, Deser et al. 2000). Vice versa, changes in the Arctic Ocean have impacts on the atmosphere. Changed high-latitude temperatures and ice concentrations have been shown to have impacts on the atmosphere as far away as in the tropics (Chiang and Bitz 2005).

Royer et al. (1990) have conducted an extreme scenario experiment with no Arctic sea ice in winter using an 
atmosphere-only model. Sea ice has been replaced by sea water at its freezing point of $271.2 \mathrm{~K}$ which equates to a $21 \mathrm{~K}$ increase of the near surface temperature at the North Pole. Winton (2008) has analysed coupled model simulations from IPCC (2007) and performed additional sensitivity experiments with no Arctic sea ice using an atmosphere-only model as well as a coupled atmosphereocean model. In the latter experiment, the ice-free Arctic has been triggered by a reduced sea ice albedo.

Magnusdottir et al. (2004) and Deser et al. (2004) have used atmosphere general circulation models (AGCMs) to investigate the impact of SST and sea ice changes on the atmosphere and found significant changes in the location of the North Atlantic storm track and the large-scale circulation. However, their prescribed SST and sea ice anomalies have been confined to the North Atlantic section of the Arctic and sub-Arctic.

Several previous studies have used predicted sea ice concentrations for the end of this century as boundary conditions for AGCM experiments: Singarayer et al. (2006) have extrapolated sea ice trends for the end of this century while Seierstad and Bader (2009) and Deser et al. (2010) use ensembles of coupled general circulation model (CGCM) predictions of sea ice concentrations. While Singarayer et al. (2006) report an intensification of the midlatitude storm tracks, Seierstad and Bader (2009) report an increase in the $500 \mathrm{hPa}$ geopotential height in winter and even more so in March with less storminess in mid-latitudes as a result. In Deser et al. (2010) the competing effects of linear and non-linear responses to boundary layer heating lead to different responses in early and late winter (baroclinic structure) and mid-winter (equivalent barotropic structure).

A climatological study comparing observed and simulated Arctic surface energy budget values and evaluating simulated changes for the future according to IPCC-AR4 model simulations indicates that there is large uncertainty regarding the components of the surface energy budget (Sorteberg et al. 2007).

Since 2007 and 2008 showed extremely low sea ice concentrations as part of a trend towards lower sea ice concentrations over the past 30 years or more, it is now possible to evaluate the impact of reduced sea ice cover on the climate from observations. Overland and Wang (2010) note a shift towards stronger easterly tropospheric winds with decreasing sea ice cover in late autumn over the past 20 years. Balmaseda et al. (2010) study the impact of the 2007 and 2008 summer sea ice anomalies on the Arctic surface energy budget and the large-scale circulation. The sea ice anomalies lead to local increases of the net shortwave radiation in excess of $30 \mathrm{~W} / \mathrm{m}^{2}$. They note that realistic mid-latitude SSTs are necessary to predict the atmospheric response to sea ice anomalies as it is highly dependent on the mid-latitude
SST distribution. CGCMs tend to show biases in the location of the Gulf and North Atlantic currents and therefore the midlatitude SST distribution. Therefore, conclusions on the feedback of Arctic sea ice cover changes to the large-scale circulation from studies with CGCMs are compromised while the impact of changed surface temperatures can be simulated more reliably.

Budikova (2009) summarizes efforts to study the role of Arctic sea ice in the general atmospheric circulation from both observations and simulations. Despite a large number of studies on this topic the uncertainty of the role of Arctic sea ice is still considerable and it is important to refine previous studies. Reasons for the uncertainty include large natural variability, the modest size of the atmospheric response to changes in Arctic sea ice as well as the coarse resolution of modelling studies. So far the highest resolution in climatological studies has been applied by Deser et al. (2010): T85L26 corresponding to a horizontal resolution of $\sim 150 \mathrm{~km}$ with 26 vertical levels.

This study aims to isolate the impact of Arctic sea ice cover and sea ice surface temperature on the atmosphere in the Arctic region and the Northern mid-latitudes without the complication of atmosphere-ocean feedbacks in a coupled atmosphere-ocean model which would alter the state of the sea not only in the Arctic region. In fact, a sensitivity study with an ice-free Arctic all over the year would not be possible in coupled mode as the Arctic would develop seasonal sea ice cover unless a strong greenhouse gas forcing or a very low ice albedo would be applied.

Implications of a reduced and removed Arctic sea ice cover for the energy budget, the large scale circulation and the surface climate are examined. In particular, we revisit the study of Royer et al. (1990) on an ice-free Arctic in winter in a much higher resolution of T255L62 $(79 \mathrm{~km}$ horizontal resolution with 62 vertical levels) and for all seasons in a climatological sense instead of only for one particular winter. Furthermore, we evaluate an additional, less extreme sensitivity experiment with reduced instead of removed sea ice cover. Results are compared to Royer et al. (1990) and other previous studies.

Section 2 deals with the set-up of experiments and the methodology regarding the energy budget evaluation. Section 3 describes the performance of the used EC-EARTH model and Sect. 4 the results of our sensitivity experiments. In Sect. 5 our results are compared to previous studies and Sect. 6 gives the summary and conclusions of this study.

\section{Set-up of experiments and methodology}

The AGCM used in this study is the atmospheric component of the coupled atmosphere-ocean-ice model ECEARTH (Hazeleger et al. 2011, this issue) which is based 
on IFS cycle 31r1 from the European Centre for MediumRange Weather Forecasting (ECMWF 2006). A few technical adaptations have been made to the original IFS model to allow it to run for long time periods. Apart from this, some limited changes in the gravity wave drag and shortwave radiation parameterizations have been applied to reproduce the observed climatology of the past 40 years as closely as possible and to achieve a balanced radiation budget.

Three 40-year experiments have been performed in T255L62 resolution corresponding to $79 \mathrm{~km}$ horizontal resolution with 62 irregularly spaced vertical levels up to $5 \mathrm{hPa}$. The reference simulation (referred to as REF) is driven by SSTs, SICs and sea ice surface temperatures (SISTs) for the years 1960-2000 from the 40-year reanalysis data set (ERA-40) compiled by the European Centre for Medium-Range Weather Forecasting (ECMWF). SSTs, SICs and SISTs in ERA-40 are taken from two main sources: the HADISST1 dataset of monthly values produced by the Met Office (Rayner et al. 2003) up to November 1981; the weekly NOAA/NCEP 2D-Var dataset (Reynolds et al. 2002) thereafter. Sea-ice analysis for both SST datasets comes from Rayner (2002).

The first sensitivity experiment is conducted with reduced sea ice concentration (SIC) and increased sea ice surface temperature (SIST), referred to as IR (ice reduced). The following has been applied throughout the year for each grid cell-note that IFS allows for a partial SIC in each grid cell:

$$
\begin{aligned}
& \mathrm{SIST} \leq \mathrm{T}_{\text {freeze }}-10^{\circ} \mathrm{C} \rightarrow \mathrm{SIST}=\mathrm{SIST}+10^{\circ} \mathrm{C}, \\
& \quad \mathrm{SIC}=\mathrm{SIC} \\
& \mathrm{SIST}>\mathrm{T}_{\text {freeze }}-10^{\circ} \mathrm{C} \rightarrow \mathrm{SST}=\operatorname{Max}\left(T_{\text {freeze }}, \mathrm{SIST}\right), \\
& \quad \mathrm{SIC}=0
\end{aligned}
$$

with $T_{\text {freeze }}$ being the freezing temperature of sea water $\left(-1.7^{\circ} \mathrm{C}\right)$.

The second sensitivity experiment assumes a sea icefree Arctic, referred to as IF (ice-free): SIC is set to 0 throughout the year in all grid cells and $\operatorname{SST}$ to $\operatorname{Max}\left(T_{\text {freeze }}\right.$, SIST) where there was sea ice before.

Figure 1 illustrates the annual cycle of SIC and surface temperature in all three experiments as an average over the area $70-90^{\circ} \mathrm{N}$. Maps of climatological seasonal means of SIC and surface temperature are shown in Figs. 2 and 3. The biggest SIC difference in IR compared to REF is prescribed in summer while the SIC difference between IR and REF is comparably minor in winter. In IF the Arctic is ice free throughout the year by definition. The biggest surface temperature difference in IR and IF compared to REF can be seen in winter leading to a reduction of the meridional temperature gradient while in summer there is hardly any difference over the Arctic sea. It should be noted that the forcing which effectively adds energy from the surface to the atmosphere has only been applied over sea areas. Changes in land surface temperatures are induced by the interaction with the warmer atmosphere in the sensitivity experiments compared to the REF experiment.

Qualitatively the assumed changes in IR agree with CMIP3 experiments. The strong decrease in the meridional surface temperature gradient in winter and the largely unchanged meridional surface temperature gradient in summer are also features in the IPCC-AR4 climate change scenario ensemble (IPCC 2007, their Figure 10.9). Furthermore, a more rapid decrease in summer sea ice compared to winter sea ice as well as a seasonally ice free Arctic is common in twenty-first century simulations. According to Winton (2008), only two out of 79 coupled climate simulations from IPCC (2007) show an all year round ice-free Arctic after nearly 300 years of simulation (with a gradual quadrupling of the present-day $\mathrm{CO}_{2}$ concentration over the first 140 years).

For the analysis of the energy budget, the area north of $70^{\circ} \mathrm{N}$ has been chosen in numerous previous studies and the same choice has been made in this study to enable a
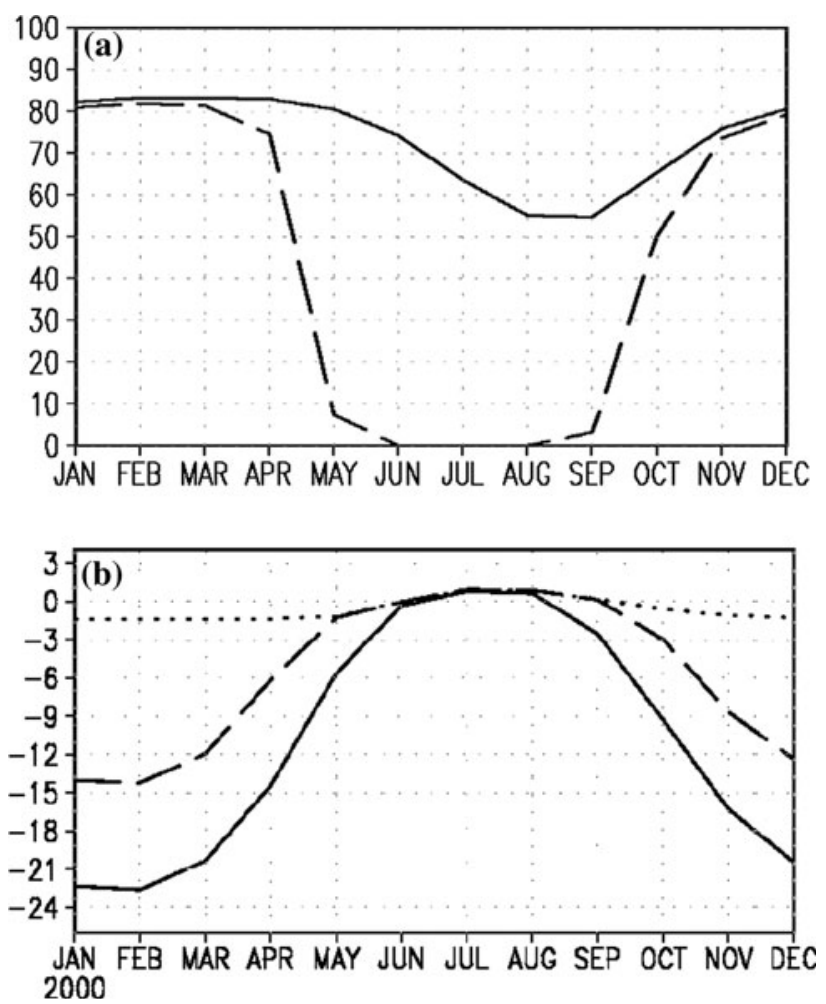

Fig. 1 a Prescribed sea ice concentration [\%] and b surface temperature $\left[{ }^{\circ} \mathrm{C}\right]$ averaged over Arctic sea grid points north of $70^{\circ} \mathrm{N}$ as climatological monthly means from 1960 to 2000. Solid line reference experiment, dashed line ice-reduced, dotted line ice-free. Please note that the dotted line does not appear for sea ice concentration because it is 0 

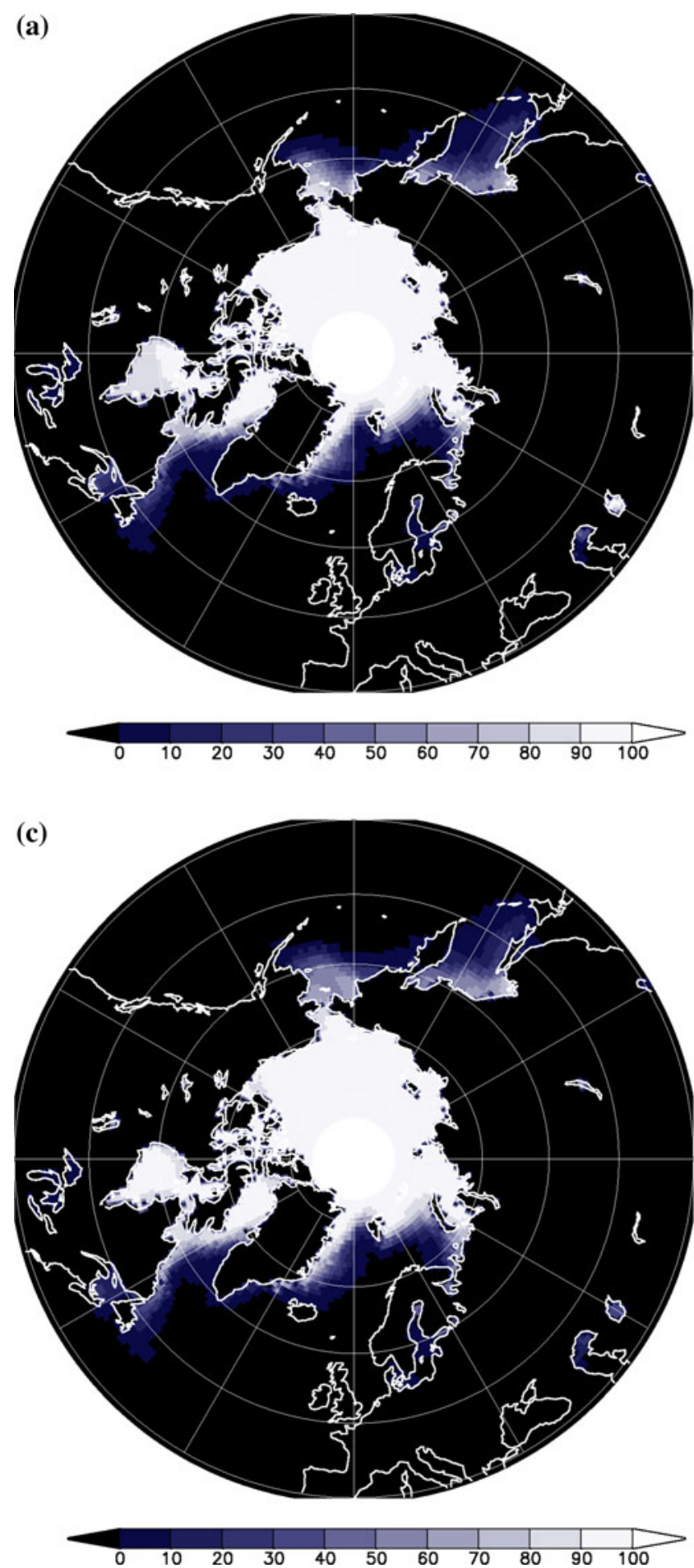

Fig. 2 Prescribed sea ice concentration [\%] as climatological seasonal means over winter (DJF) months 1960-2000 a in the reference experiment and $\mathbf{b}$ in the ice-reduced experiment. $\mathbf{c}$ and d same as a and b but climatological seasonal means over spring

comparison. At the top of the atmosphere (TOA) net shortwave and longwave radiation are considered and at the surface net shortwave and longwave radiation as well as sensible and latent heat fluxes. Note that the melting
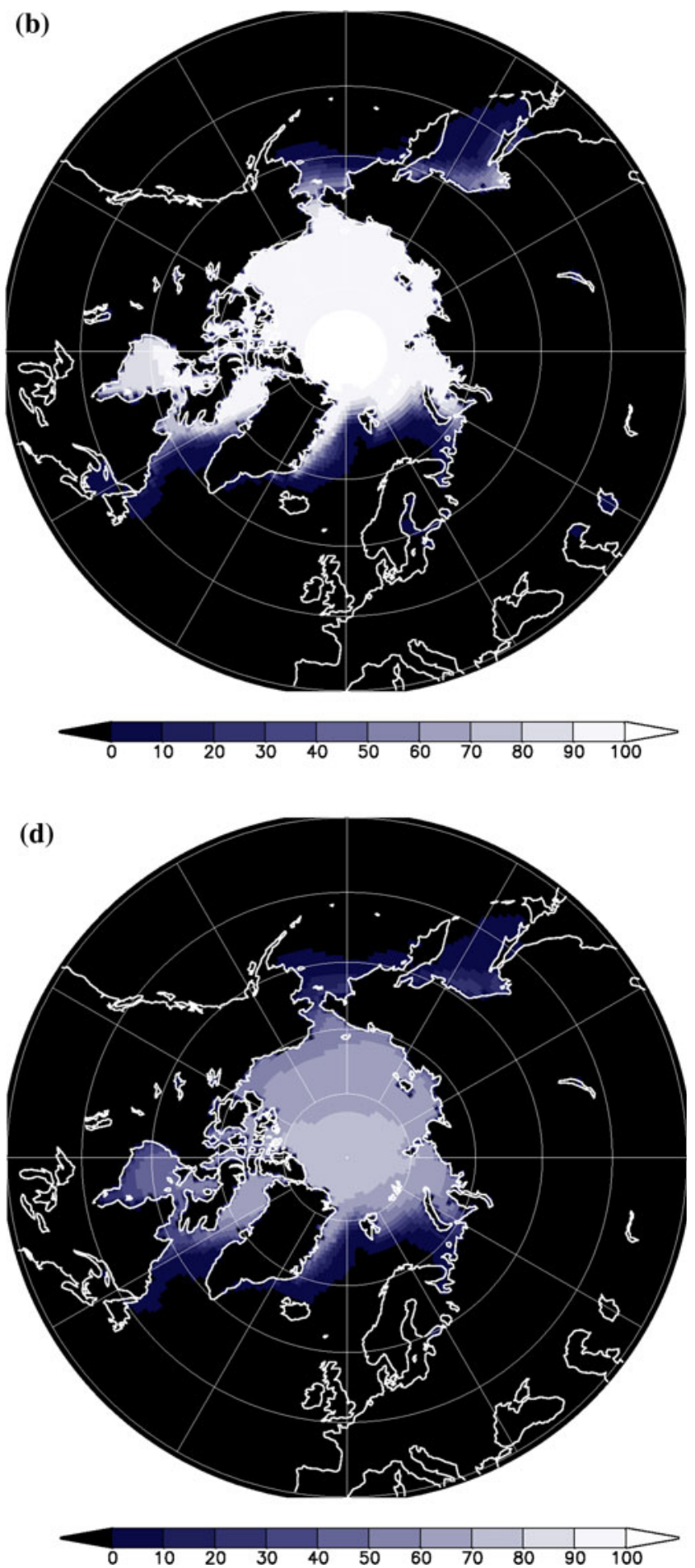

(MAM) months 1960-2000, e, f climatological seasonal means over summer (JJA) months 1960-2000 and g, h climatological seasonal means over autumn (SON) months 1960-2000

energy is neglected here as it has been shown, for example in Semmler et al. (2005), that it is small $\left(-1 \mathrm{~W} / \mathrm{m}^{2}\right.$ averaged over the whole year). We define downward fluxes positive and upward fluxes negative. 

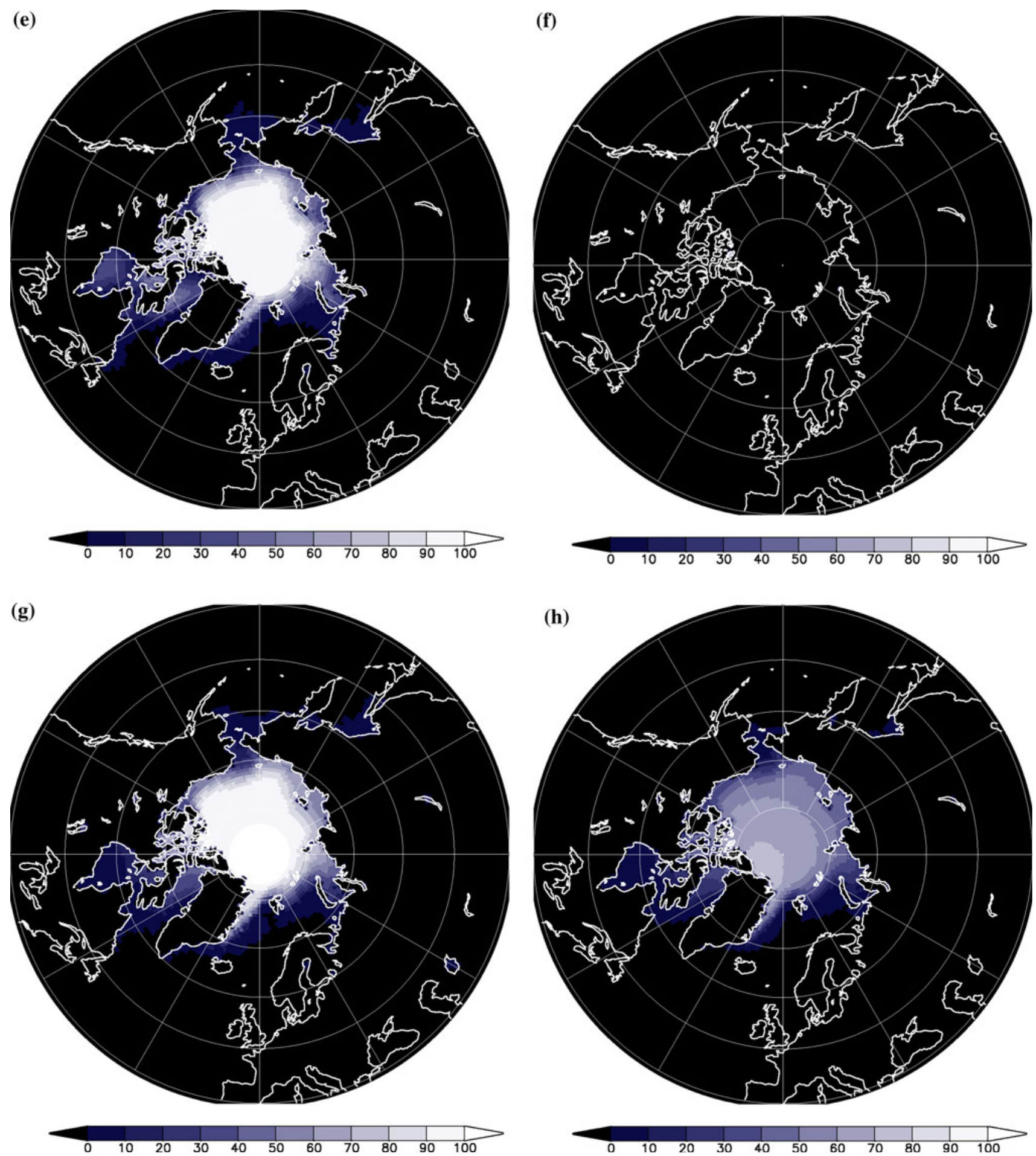

Fig. 2 continued

The lateral energy transport across $70^{\circ} \mathrm{N}$ can be calculated as a residual value if the change in the total energy content of the Arctic atmosphere north of $70^{\circ} \mathrm{N}$ is known. The total energy content is calculated as a vertical integral over the atmospheric column normalized with the area as in Serreze et al. (2007b): $d E_{A} / d t=d / d t 1 / g \int_{0}^{p_{s}}\left(c_{p} T+k+L q+g z\right) d p$

with $E_{A}$ being the total energy content divided by the area, $t$ the time, $g$ the gravitational constant $\left(9.80665 \mathrm{~m} / \mathrm{s}^{2}\right), p_{s}$ 

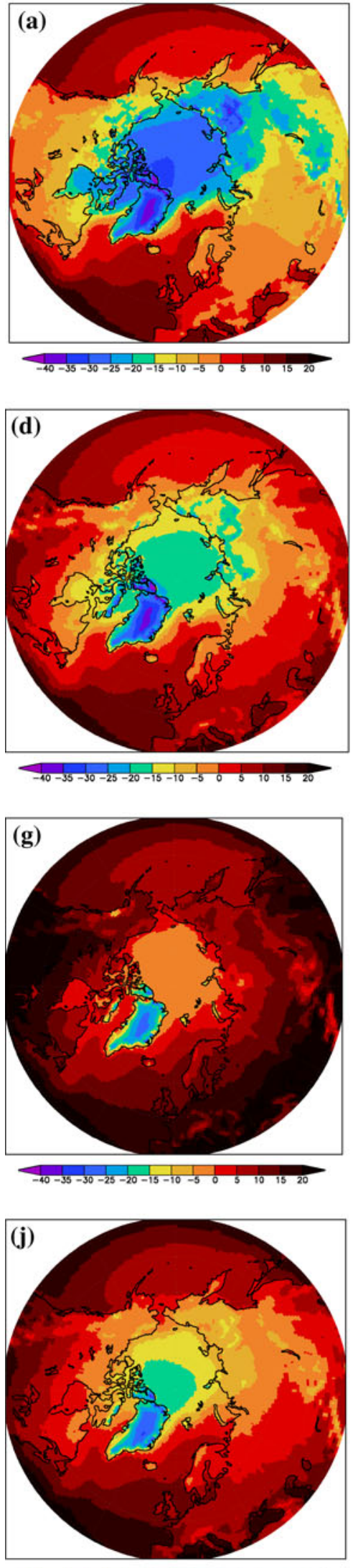

$4-40-35-30-25-20-15-10-5 \quad 6 \quad 5 \quad 10 \quad 1520$
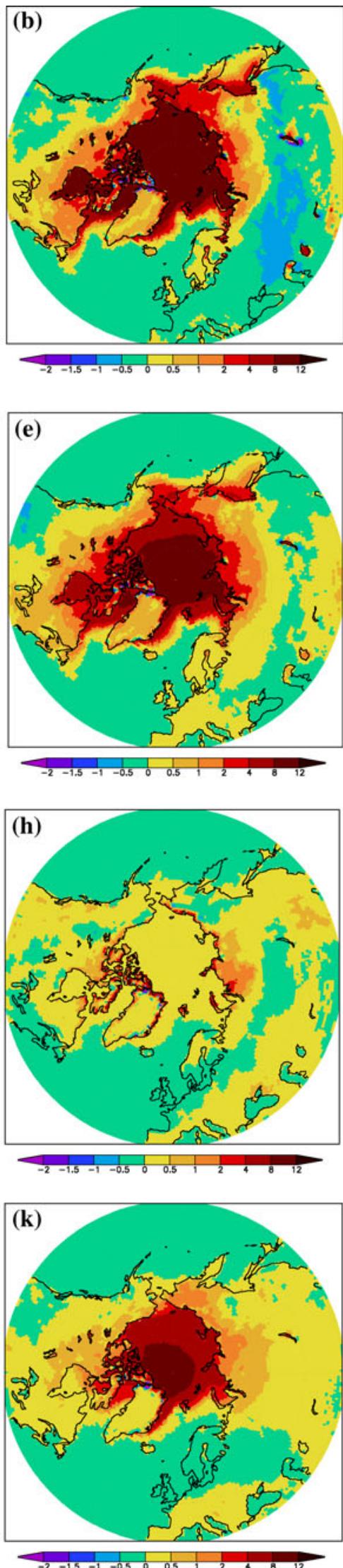
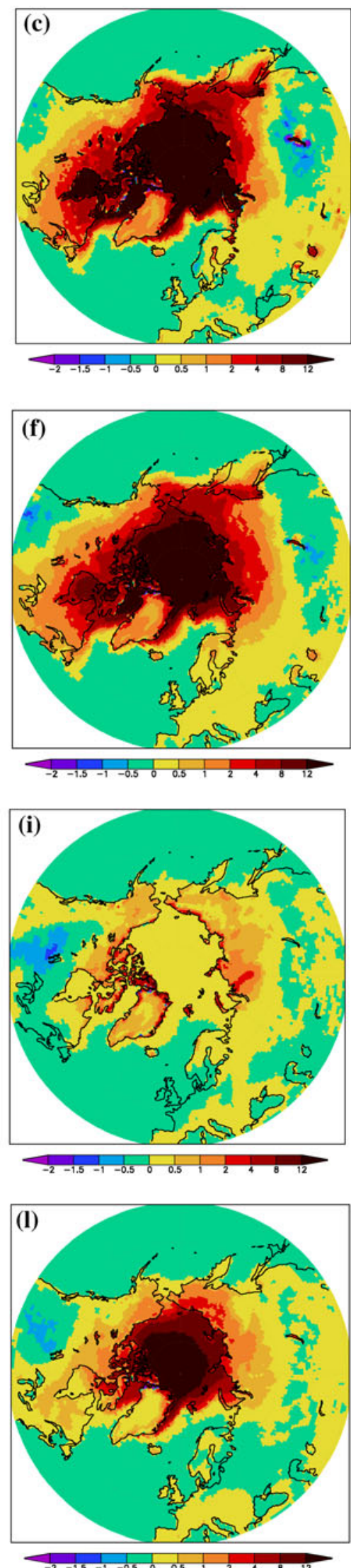
Fig. 3 Surface temperature $\left[{ }^{\circ} \mathrm{C}\right]$ over the Arctic and the Northern mid-latitudes as climatological seasonal means for winter 1960-2000 from a reference experiment, b surface temperature difference $\left[{ }^{\circ} \mathrm{C}\right.$ ] ice-reduced minus reference experiment for winter 1960-2000, c surface temperature difference $\left[{ }^{\circ} \mathrm{C}\right]$ ice-free minus reference experiment for winter 1960-2000. d-f same as a-c but for spring 1960-2000, $\mathbf{g}-\mathbf{i}$ for summer 1960-2000 and $\mathbf{j}-\mathbf{l}$ for autumn 1960-2000. Over sea the surface temperature is prescribed and over land it is simulated

the surface pressure, $c_{p}$ the specific heat of the atmosphere $[1,005.7 \mathrm{~J} /(\mathrm{kg} \mathrm{K})], T$ the temperature in $\mathrm{K}, k$ the kinetic energy, $L$ the latent heat of evaporation $\left(2.501 \times 10^{6} \mathrm{~J} /\right.$ $\mathrm{kg}), q$ the specific humidity, $z$ the height and $p$ the pressure. The kinetic energy term is typically small and is neglected as in Nakamura and Oort (1988).

\section{Performance of EC-EARTH}

The EC-EARTH model has been extensively evaluated against observations in Hazeleger et al. (2010) and Hazeleger et al. (2011, this issue). In those studies it has been shown that the uncoupled atmosphere-only model and the coupled atmosphere-ocean-ice model are at least as close to observations as the average over the range of models used for the 4th assessment report of the Intergovernmental Panel on Climate Change (IPCC 2007). However, the performance in terms of the Arctic energy budget has not been investigated yet and therefore an evaluation is presented here.

Table 1 shows components of the surface energy budget averaged over the area north of $70^{\circ} \mathrm{N}$ for the REF experiment and for previous studies. In general the annual cycle of the budget is similar between simulations (this study and Semmler et al. 2005) and observations (Serreze et al. 2007b and Porter et al. 2010). Note that reanalysis data are model data with an assimilation of observation data-for simplicity they are referred to as observation data here and in the following. Summer is the only season showing a positive energy balance at the earth (sea and land) surface, with the highest values in Porter et al. (2010). It is to be noted that there still is considerable uncertainty in the components of the surface energy budget when comparing values from different observation sources according to Sorteberg et al. (2007). For the yearly averaged net surface longwave radiation and the latent heat flux, our reference simulation agrees well with the observations of Sorteberg et al. (2007) within the uncertainty of these measurements, although the net surface longwave radiation is less negative compared to ERA-40 data. Our net surface shortwave radiation is smaller than the given range in Sorteberg et al. (2007) while the sensible heat flux is slightly negative in the two modelling studies and close to zero in the ERA-40 data and in Sorteberg et al. (2007), but it is positive in the NCEP reanalysis data.

At the top of the atmosphere (TOA, Table 2) only the regional climate model in Semmler et al. (2005) and the Japanese 25 Year Reanalysis (JRA-25) evaluated by Porter et al. (2010) show a budget close to zero in summer while all other data including the present study show an energy loss from the atmosphere to the space between 6 and $25 \mathrm{~W} /$ $\mathrm{m}^{2}$. The different result at the top of the atmosphere in Semmler et al. (2005) comes from a stronger net TOA shortwave radiation in those data in summer. It is encouraging that our results of the TOA energy budget are generally in the range of values from previous observation studies (Serreze and Barry 2005; Serreze et al. 2007b; Porter et al. 2010). Also, for the components of the TOA budget (net shortwave and net longwave radiation), our values are between those in Serreze and Barry (2005) and those from the ERA-40 data.

To calculate the lateral energy transport across $70^{\circ} \mathrm{N}$ as a residual, it is necessary to determine the total energy content of the Arctic atmosphere at the beginning and at the end of the simulation. From Table 3 showing the total energy content in the years 1960 and 2000 and the resulting flux over the 40 years it becomes clear that the difference between the total energy content at the beginning and at the end of the simulation is negligible. The resulting flux is several orders of magnitude smaller than any of the simulated fluxes or a typical $20^{\text {th }}$ century climate change signal of $1 \mathrm{~W} / \mathrm{m}^{2}$.

The lateral energy transport across $70^{\circ} \mathrm{N}$ is very close to $100 \mathrm{~W} / \mathrm{m}^{2}$ in all four studies in which values for both the surface and the TOA budget are given (incoming energy across $70^{\circ} \mathrm{N}$ distributed over the area north of $70^{\circ} \mathrm{N}$ ). From the present study it is $100 \mathrm{~W} / \mathrm{m}^{2}$, from Semmler et al. (2005) $98 \mathrm{~W} / \mathrm{m}^{2}$, from Serreze et al. (2007b) $99 \mathrm{~W} / \mathrm{m}^{2}$ and from Porter et al. (2010) 94-105 W/m².

\section{Results of sensitivity studies}

\subsection{Cloud cover}

In our sensitivity experiments cloud cover, vertically integrated liquid water content and vertically integrated ice content (Fig. 4) slightly decrease in summer possibly because of slightly less latent heat flux over the Arctic ocean in this season (Fig. 5). This allows more incoming shortwave radiation to reach the surface.

In winter and early spring the cloud cover slightly increases in the IR experiment by up to $2 \%$ while it strongly decreases in the IF experiment by about $10 \%$. Here two effects might be competing: the stronger evaporation due to the higher surface temperature and the less 
Table 1 Components of the surface energy budget averaged over the area north of $70^{\circ}$

\begin{tabular}{|c|c|c|c|c|c|c|c|c|c|c|c|c|c|c|c|c|c|c|c|c|c|}
\hline \multirow[b]{2}{*}{ Year } & \multicolumn{4}{|c|}{ Net shortwave radiation } & \multicolumn{4}{|c|}{ Net longwave radiation } & \multicolumn{5}{|c|}{ Sensible heat flux } & \multicolumn{3}{|c|}{ Latent heat flux } & \multicolumn{5}{|c|}{ Budget } \\
\hline & $38 \quad 42$ & 42 & 43 & $50--$ & -38 & $-34-41$ & -28 & $52--$ & -2 & -3 & 0 & 0 & $10^{--}$ & $-12-11-12$ & -13 & & -14 & - & -11 & -- & -5 to -14 \\
\hline Winter & 1 & 1 & -- & -- & -44 & $-38-48$ & -- & -- & -2 & -3 & 2 & -- & -- & $-11-12-10$ & -- & -- & -56 & -53 & -55 & -- & -51 to -65 \\
\hline Spring & $45 \quad 48$ & 47 & -- & -- & -42 & $-39-49$ & -- & -- & -1 & -1 & 0 & -- & -- & $\begin{array}{lll}-10 & -12 & -11\end{array}$ & -- & -- & -8 & -4 & -13 & -- & -9 to -11 \\
\hline Summer & $98 \quad 113$ & 110 & -- & -- & -28 & $-33-31$ & -- & -- & -1 & -6 & 0 & -- & -- & $\begin{array}{lll}-12 & -7 & -14\end{array}$ & -- & -- & 57 & 67 & 65 & -- & 71 to 79 \\
\hline Autumn & 10 & 11 & -- & -- & -37 & $-28-38$ & -- & -- & & -1 & -1 & - & -- & $\begin{array}{lll}-13 & -13 & -13\end{array}$ & -- & -- & -44 & -34 & -42 & -- & -37 to -52 \\
\hline
\end{tabular}

In each cell the first value corresponds to the REF simulation of this study, the second to a regional climate model simulation by Semmler et al. (2005), the third to calculations from ERA-40 reanalysis data by Serreze et al. (2007b) for the budget values and by us for the components, the fourth to calculations from a range of satellite observation and reanalysis data by Sorteberg et al. (2007) (ranges are given) and the fifth to calculations from National Centre for Environmental Prediction (NCEP) reanalysis and Japanese 25 Year Reanalysis (JRA-25) data by Porter et al. (2010) (ranges are given). All values are given in W/m² as climatological mean values, positive downward, negative upward. '-' Means no data available

Table 2 Components of the top of atmosphere energy budget averaged over the area north of $70^{\circ} \mathrm{N}$

\begin{tabular}{|c|c|c|c|c|c|c|c|c|c|c|c|c|c|c|c|}
\hline \multirow[b]{2}{*}{ Year } & \multicolumn{5}{|c|}{ Net shortwave radiation } & \multicolumn{5}{|c|}{ Net longwave radiation } & \multicolumn{5}{|c|}{ Budget } \\
\hline & 83 & 94 & 78 & 90 & -- & -197 & -198 & -191 & -200 & -- & -114 & -104 & -113 & -110 & -107 to -109 \\
\hline Winter & 2 & 2 & 1 & 2 & -- & -173 & -172 & -165 & -177 & -- & -171 & -170 & -164 & -175 & -169 to -178 \\
\hline Spring & 104 & 119 & 89 & 112 & -- & -196 & -197 & -189 & -198 & -- & -92 & -78 & -100 & -86 & -77 to -91 \\
\hline Summer & 202 & 231 & 196 & 218 & -- & -224 & -230 & -221 & -228 & -- & -22 & 1 & -25 & -11 & -3 to -15 \\
\hline Autumn & 26 & 24 & 25 & 28 & -- & -195 & -193 & -188 & -198 & -- & -169 & -169 & -163 & -171 & -160 to -171 \\
\hline
\end{tabular}

In each cell the first value corresponds to the REF simulation of this study, the second to a regional climate model simulation by Semmler et al. (2005), the third to a calculation from satellite data by Serreze and Barry (2005), their Table 3.1, the fourth to calculations from ERA-40 reanalysis data by Serreze et al. (2007b) for the budget values and by us for the components and the fifth to calculations from a range of reanalysis and satellite data by Porter et al. (2010) (ranges are given). All values are given in $\mathrm{W} / \mathrm{m}^{2}$ as climatological mean values, positive downward, negative upward. '-' Means no data available

Table 3 Total energy content in the three simulations in the years 1960 and 2000, difference of total energy content 2000 minus 1960 and resulting flux over the 40 years

\begin{tabular}{llll}
\hline & REF & IR & IF \\
\hline Total energy 1960 & $3.2141 \times 10^{9} \mathrm{~J} / \mathrm{m}^{2}$ & $3.2150 \times 10^{9} \mathrm{~J} / \mathrm{m}^{2}$ & $3.2318 \times 10^{9} \mathrm{~J} / \mathrm{m}^{2}$ \\
Total energy 2000 & $3.1959 \times 10^{9} \mathrm{~J} / \mathrm{m}^{2}$ & $3.2131 \times 10^{9} \mathrm{~J} / \mathrm{m}^{2}$ & $3.2221 \times 10^{9} \mathrm{~J} / \mathrm{m}^{2}$ \\
Total energy difference 2000-1960 & $-1.82 \times 10^{7} \mathrm{~J} / \mathrm{m}^{2}$ & $-1.9 \times 10^{6} \mathrm{~J} / \mathrm{m}^{2}$ & $-9.7 \times 10^{6} \mathrm{~J} / \mathrm{m}^{2}$ \\
Flux & $-0.0144 \mathrm{~W} / \mathrm{m}^{2}$ & $-0.00151 \mathrm{~W} / \mathrm{m}^{2}$ & $-0.0077 \mathrm{~W} / \mathrm{m}^{2}$ \\
\hline
\end{tabular}

stable situation leading to more mixing and less inversion induced clouds. In addition, circulation changes might play a role. Similarly, the vertically integrated ice content increases in the IR experiment while it decreases in the IF experiment in winter and early spring. However, the vertically integrated water content increases in the IR experiment and even more so in the IF experiment. This means that the ratio of liquid to ice content in clouds does not change strongly in the IR experiment while it clearly changes towards a larger liquid water proportion in the IF experiment due to the strongly increased temperature. Therefore, the optical thickness of clouds remains largely 

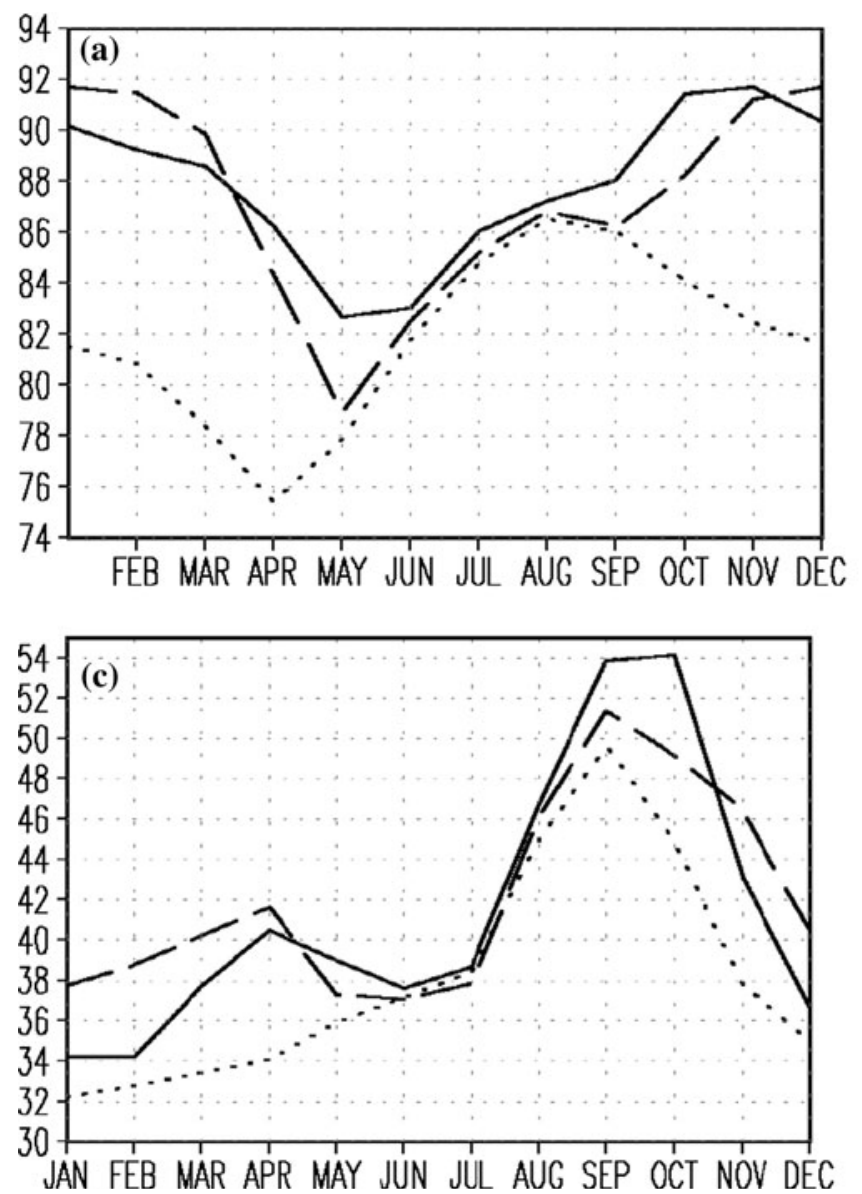

Fig. 4 a Total cloud cover [\%], b vertically integrated liquid water $[\mathrm{g} / \mathrm{kg}]$ and $\mathbf{c}$ vertically integrated ice content $[\mathrm{g} / \mathrm{kg}]$ averaged over 70 to $90^{\circ} \mathrm{N}$ as climatological monthly means from 1960 to 2000 . Solid

unchanged in the IR experiment while clouds become optically thicker in the IF experiment in winter and early spring.

In late spring and autumn there is less cloud cover in the sensitivity experiments than in the reference experiment while there is slightly more liquid water content and less ice content making the clouds optically thicker in both sensitivity experiments in these seasons.

\subsection{Energy budget}

As expected, the components of both the surface energy budget (Table 4) and the TOA energy budget (Table 5) are substantially changed in our sensitivity experiments IR and IF compared to the reference experiment REF. Comparing the IR with the REF simulation, both the net surface and the net TOA shortwave radiation increase by $24-37 \mathrm{~W} / \mathrm{m}^{2}$ in spring and summer due to the strongly decreased sea ice cover (Figs. 1, 2), the reduced cloud cover and the associated decreased surface and planetary albedos. In the IF simulation this increase amounts to up to $44 \mathrm{~W} / \mathrm{m}^{2}$ in

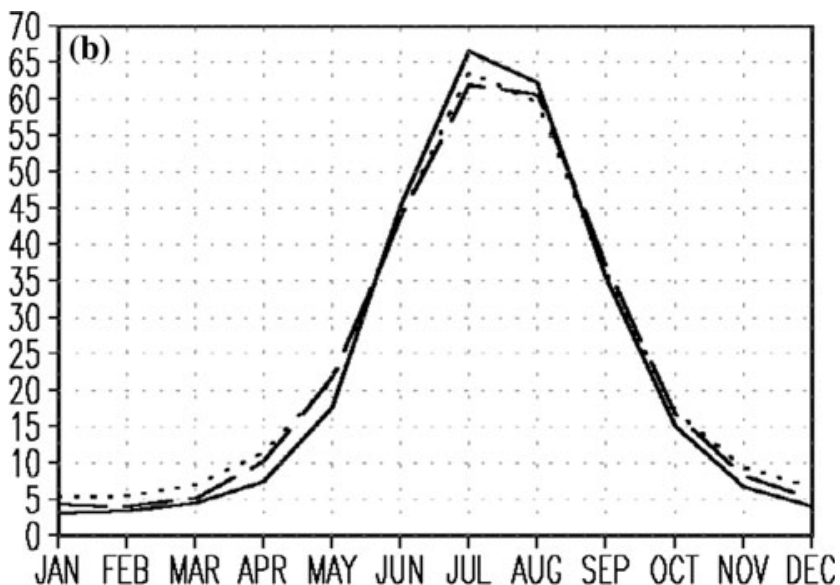

line reference experiment, dashed line ice-reduced experiment, dotted line ice-free experiment

spring. In autumn and winter changes in the surface and TOA net shortwave radiation are small because there is only little or no incoming shortwave radiation.

The net surface and net TOA longwave radiation is slightly more negative in all seasons except the summer in which the surface temperature is hardly changed in the sensitivity experiments compared to REF. In the winter season of the IF experiment there is a substantial change towards stronger negative values by $23 \mathrm{~W} / \mathrm{m}^{2}$ in the net surface longwave radiation and $20 \mathrm{~W} / \mathrm{m}^{2}$ in the net TOA longwave radiation.

Surface sensible and latent heat fluxes are generally slightly stronger upward directed in IR compared to REF simulation. In the IF simulation these changes are larger, especially in winter. The strong changes in the IF experiment compared to the REF experiment in winter are expected due to the strongly increased surface temperature in this experiment.

The described changes in surface radiative and turbulent fluxes in the sensitivity experiments compared to the REF experiment lead to more positive budget values in spring 

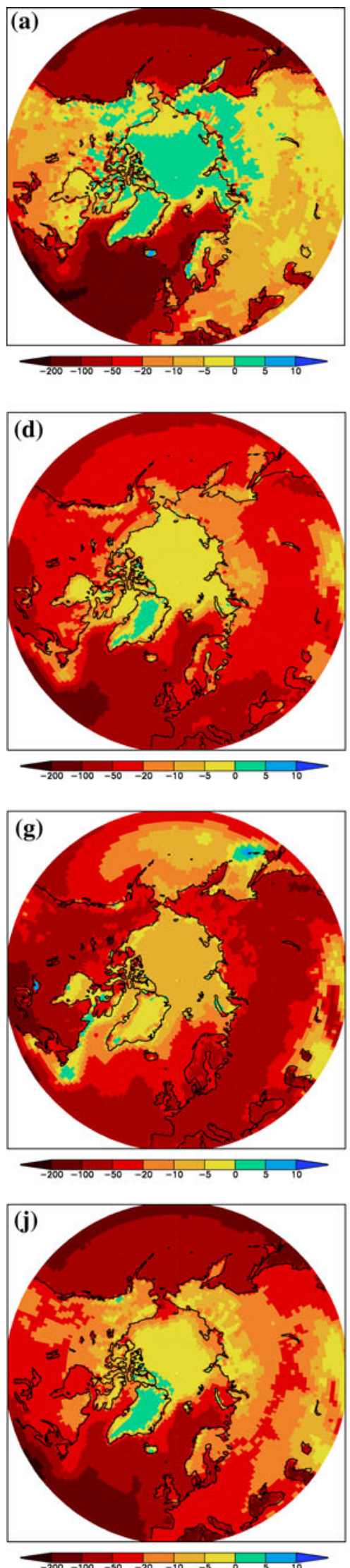
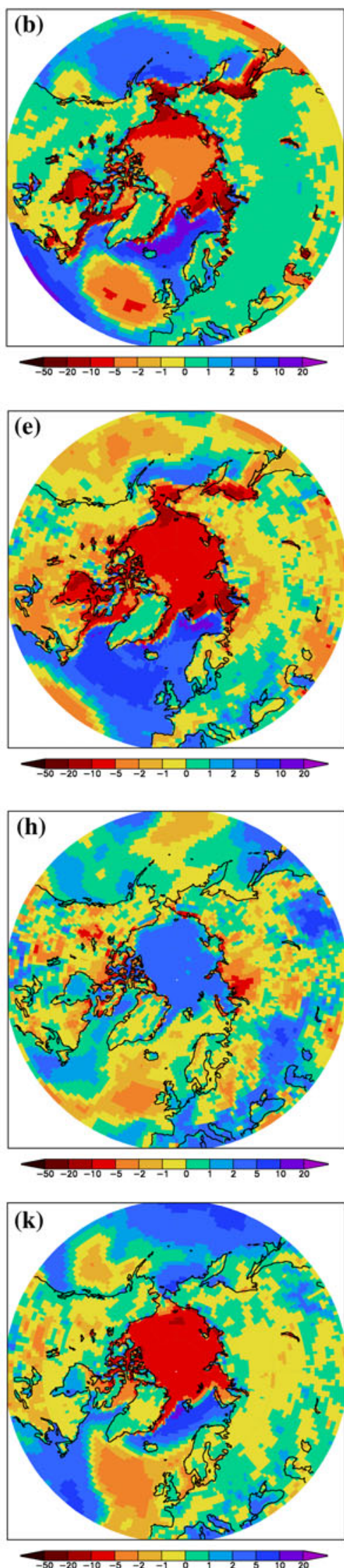
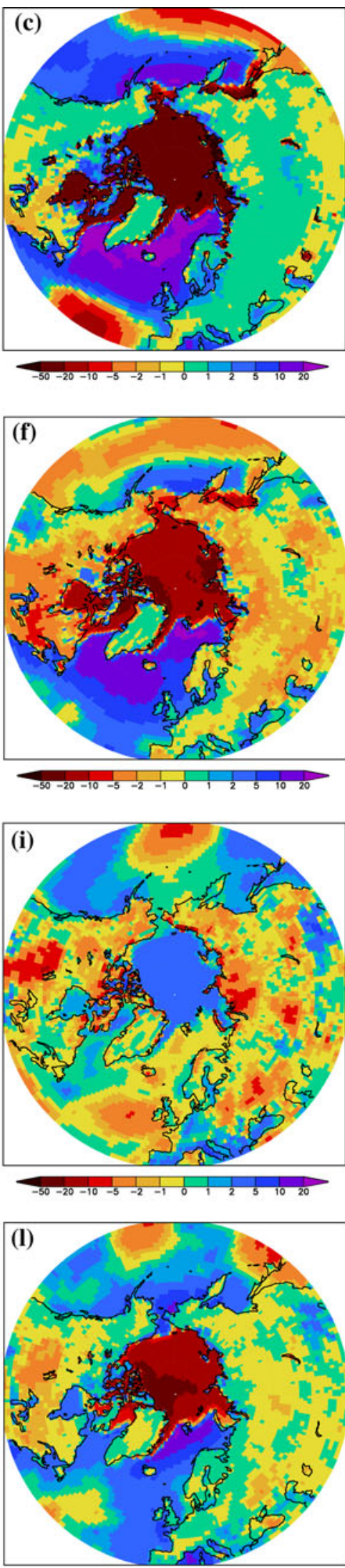

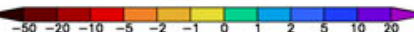


Fig. 5 Latent heat flux $\left[\mathrm{W} / \mathrm{m}^{2}\right]$ over the Arctic and the Northern midlatitudes as climatological seasonal means for winter 1960-2000 from a reference experiment, b difference in latent heat flux $\left[\mathrm{W} / \mathrm{m}^{2}\right]$ icereduced minus reference experiment for winter 1960-2000, c difference in latent heat flux $\left[\mathrm{W} / \mathrm{m}^{2}\right]$ ice-free minus reference experiment for winter 1960-2000. d-f same as a-c but for spring 1960-2000, gi for summer 1960-2000 and $\mathbf{j}-\mathbf{l}$ for autumn 1960-2000

and summer and more negative ones in autumn and winter. The annually averaged loss of energy from the earth (sea and land) surface to the atmosphere decreases by $7 \mathrm{~W} / \mathrm{m}^{2}$ in the IR compared to the REF experiment and increases by $8 \mathrm{~W} / \mathrm{m}^{2}$ in the IF compared to the REF experiment.

Also at the TOA more positive budget values are simulated in our sensitivity experiments in spring and summer and more negative ones in autumn and winter. At the TOA, the loss of energy decreases by about $10 \mathrm{~W} / \mathrm{m}^{2}$ in both sensitivity experiments averaged over the year.
For the IR and IF experiments the annually averaged total heat content of the Arctic atmosphere is very similar at the beginning and at the end of the simulations as for the REF experiment (Table 3). Therefore, it can be concluded that $96 \mathrm{~W} / \mathrm{m}^{2}$ are transported from the mid-latitudes across $70^{\circ} \mathrm{N}$ in the IR experiment and $82 \mathrm{~W} / \mathrm{m}^{2}$ in the IF experiment, 4 and $18 \mathrm{~W} / \mathrm{m}^{2}$ less than in the $\mathrm{REF}$ experiment.

\subsection{Large-scale circulation}

While the energy budget is strongly affected by the prescribed surface changes of our sensitivity experiments in all seasons, the large-scale circulation shows the strongest changes in winter and the weakest in summer.

In winter and spring negative mean sea level pressure anomalies can be seen over the Western Arctic sea areas

Table 4 Components of the surface energy budget averaged over the area north of $70^{\circ} \mathrm{N}$

\begin{tabular}{|c|c|c|c|c|c|c|c|c|c|c|c|c|c|c|c|}
\hline & \multicolumn{3}{|c|}{$\begin{array}{l}\text { Net shortwave } \\
\text { radiation }\end{array}$} & \multicolumn{3}{|c|}{$\begin{array}{l}\text { Net longwave } \\
\text { radiation }\end{array}$} & \multicolumn{3}{|c|}{ Sensible heat flux } & \multicolumn{3}{|c|}{ Latent heat flux } & \multicolumn{3}{|c|}{ Budget } \\
\hline Year & 38 & 54 & 59 & -38 & -42 & -51 & -2 & -5 & -9 & -12 & -14 & -21 & -14 & -7 & -22 \\
\hline Winter & 1 & 0 & 1 & -44 & -49 & -67 & -2 & -8 & -19 & -11 & -14 & -31 & -56 & -71 & -116 \\
\hline Spring & 45 & 70 & 89 & -42 & -48 & -57 & -1 & -5 & -6 & -10 & -15 & -19 & -8 & 2 & 7 \\
\hline Summer & 98 & 135 & 135 & -28 & -29 & -29 & -1 & -2 & -2 & -12 & -11 & -12 & 57 & 93 & 92 \\
\hline Autumn & 10 & 13 & 13 & -37 & -43 & -50 & -4 & -6 & -8 & -13 & -17 & -21 & -44 & -53 & -66 \\
\hline
\end{tabular}

In each cell the first value corresponds to the REF, the second to the IR and the third to the IF simulation. All values are given in $\mathrm{W} / \mathrm{m}^{2}$ as climatological mean values for 1960-2000, positive downward, negative upward

Table 5 Components of the top of atmosphere energy budget averaged over the area north of $70^{\circ} \mathrm{N}$

\begin{tabular}{|c|c|c|c|c|c|c|c|c|c|}
\hline \multirow[b]{2}{*}{ Year } & \multicolumn{3}{|c|}{ Net shortwave radiation } & \multicolumn{3}{|c|}{ Net longwave radiation } & \multicolumn{3}{|c|}{ Budget } \\
\hline & 83 & 98 & 103 & -197 & -201 & -207 & -114 & -103 & -104 \\
\hline Winter & 2 & 2 & 2 & -173 & -180 & -193 & -171 & -178 & -191 \\
\hline Spring & 104 & 128 & 145 & -196 & -201 & -208 & -92 & -73 & -63 \\
\hline Summer & 202 & 235 & 235 & -224 & -224 & -224 & -22 & 11 & 11 \\
\hline Autumn & 26 & 28 & 8 & -195 & -199 & -202 & -169 & -171 & -174 \\
\hline
\end{tabular}

In each cell the first value corresponds to the REF, the second to the IR and the third to the IF simulation. All values are given in $\mathrm{W} / \mathrm{m}^{2}$ as climatological mean values for 1960-2000, positive downward, negative upward 

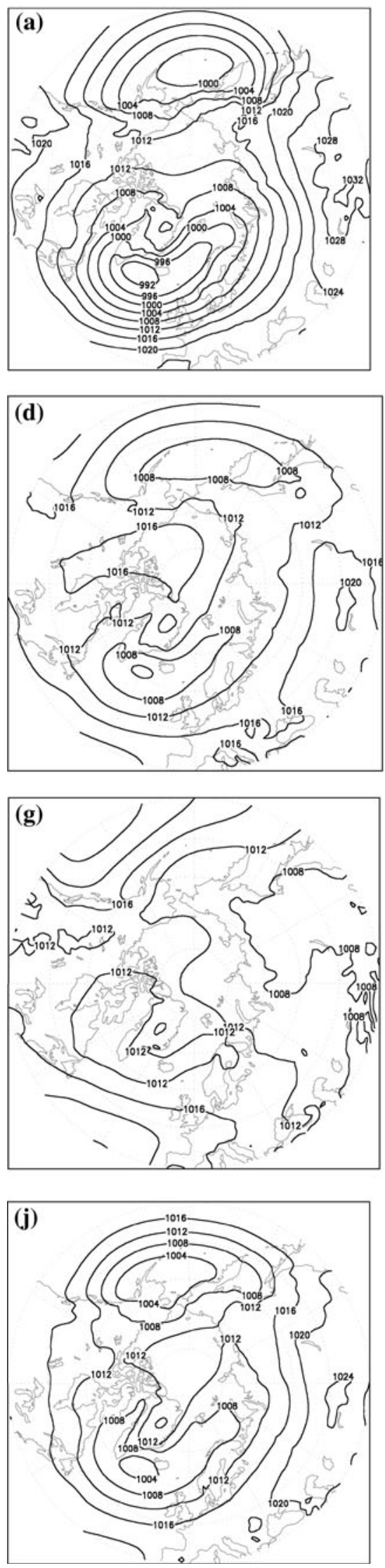
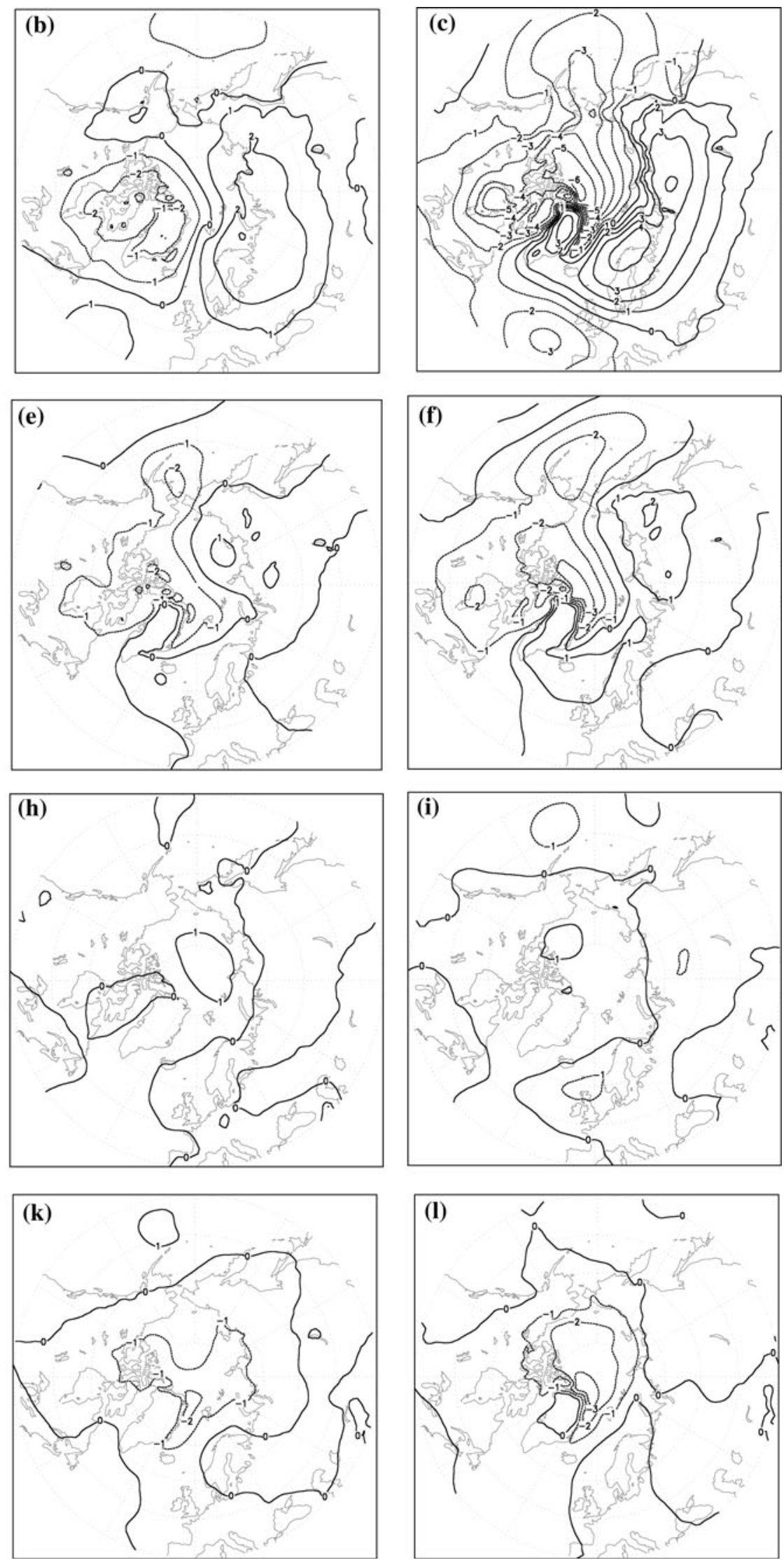
4 Fig. 6 Mean sea level pressure $[\mathrm{hPa}]$ over the Arctic and the Northern mid-latitudes as climatological seasonal means for winter 1960-2000 from a reference experiment, b mean sea level pressure difference $[\mathrm{hPa}]$ ice-reduced minus reference experiment for winter 1960-2000, c mean sea level pressure difference [hPa] ice-free minus reference experiment for winter 1960-2000. d-f same as a-c but for spring 1960-2000, g-i for summer 1960-2000 and $\mathbf{j}-\mathbf{l}$ for autumn 1960-2000

and positive anomalies over the Eastern continental Arctic (Fig. 6). Anomalies are stronger in winter compared to spring and in IF compared to IR. The mean sea level pressure decreases by $6 \mathrm{hPa}$ north of Greenland and increases by $4 \mathrm{hPa}$ over Northern Norway and over Siberia in winter in the IF experiment compared to the REF experiment. In summer only minor differences of up to $1 \mathrm{hPa}$ are simulated with positive anomalies over the Central Arctic. In the IF experiment minor negative anomalies are simulated south of the Aleutian Islands, over parts of Siberia and north of the UK.

In autumn the response is much more symmetric than in winter and spring. The asymmetric response in winter and spring and the symmetric response in autumn are likely to be connected to the surface temperature forcing. In winter and spring the positive surface temperature forcing is not only strong in the Central Arctic but also in the Hudson Bay and the Canadian Archipelago (Fig. 3). In autumn the positive surface temperature forcing is more symmetric and concentrated on the Central Arctic. This forcing leads to increased upward sensible and latent heat fluxes (Fig. 5). Therefore, a surface trough can develop in the Western Arctic in winter and spring, and in the Central Arctic in autumn. In summer slightly decreased upward latent heat fluxes with only little change in sensible heat fluxes over the open water lead to the opposite effect in the Central Arctic.

The geopotential height increases by $40 \mathrm{~m}$ in the Eastern Arctic in IR compared to REF and by $80 \mathrm{~m}$ in the extreme experiment IF (Fig. 7). In spring the signal is somewhat weaker (30 $\mathrm{m}$ in IR and $60 \mathrm{~m}$ in IF) and shifted more away from the North Pole towards the Siberian coast. The increase of the geopotential height over the entire Arctic can be attributed to warmer temperatures in the lower troposphere while the shift of the maximum towards the Siberian coast can be explained by the mean sea level pressure anomaly. In summer and autumn changes are generally small (10 m, except for IF experiment in autumn: $30 \mathrm{~m}$ ) and the geopotential increase is centred on the Central Arctic except for the IF experiment in summer where the geopotential increase is shifted towards Alaska.

Figure 8 shows zonally averaged cross sections of the Northern Hemispheric response to the modified sea ice and surface temperature conditions for winter. The geopotential height response is present in the whole Arctic troposphere and increases with increasing height. This is due to the increased tropospheric temperature in the Arctic which is most pronounced close to the surface but which still amounts to about $1{ }^{\circ} \mathrm{C}$ in the IR and $2{ }^{\circ} \mathrm{C}$ in the IF experiment at $600 \mathrm{hPa}$. A weakening of the circulation cells with higher geopotential in the Arctic, less westerly wind in the Northern mid-latitudes and parts of the Arctic, less easterly flow in the subtropics as well as less vertical motion is simulated. Relative adiabatic cooling through upward motion anomalies can take place as can be seen around $40-50^{\circ} \mathrm{N}$ in the middle troposphere.

\subsection{Surface climate in the Northern mid-latitudes}

While the strongest differences between the sensitivity experiments and the reference experiment occur in the Arctic, substantial changes also occur in the Northern midlatitudes. The surface temperature (Fig. 3) is warmer in all coastal areas surrounding the Arctic ocean in both sensitivity experiments compared to REF. Differences are strongest in winter and weakest in summer and stronger in IF than in IR. They amount to up to $10^{\circ} \mathrm{C}$ in winter in the IF simulation over East Siberia and the Canadian Archipelago and up to $2{ }^{\circ} \mathrm{C}$ in summer in the IR simulation over the same areas. While in winter, spring and autumn the differences are caused by less cold air advection due to the surface temperature forcing in the neighbouring Arctic ocean area, in summer the Arctic ocean has a similar surface temperature in the three simulations and differences may be caused by warmer soil temperatures.

It is noteworthy that over Europe the sensitivity experiments show similar surface temperatures compared to REF in all seasons while the surface temperature over North America and Siberia is more affected by the warmer Arctic surface temperature. The reason is that Europe is strongly influenced by the North Atlantic SST which is not changed in the sensitivity experiments while North America and Siberia represent more substantial land masses. In winter colder surface temperature is simulated in IR compared to REF over parts of Eastern Europe, possibly due to a less pronounced westerly flow and therefore less heat transport from the North Atlantic.

Extreme cold events in winter are generally less intense in IR and IF compared to REF over large parts of the Northern mid-latitudes. There are large regions in Canada in which the 1 st percentile of daily mean $2 \mathrm{~m}$ temperature in winter increases by more than $2^{\circ} \mathrm{C}$ in IR and more than $5^{\circ} \mathrm{C}$ in IF (Fig. 9). This is not surprising as in situations with a northerly flow less cold air is advected because of the prescribed higher surface temperatures in the Arctic. Changes in the 50th percentile are less pronounced and restricted to areas close to where the surface forcing is applied. Notable also is that in some Central and Eastern European regions decreases of the 1st and 50th percentile of 

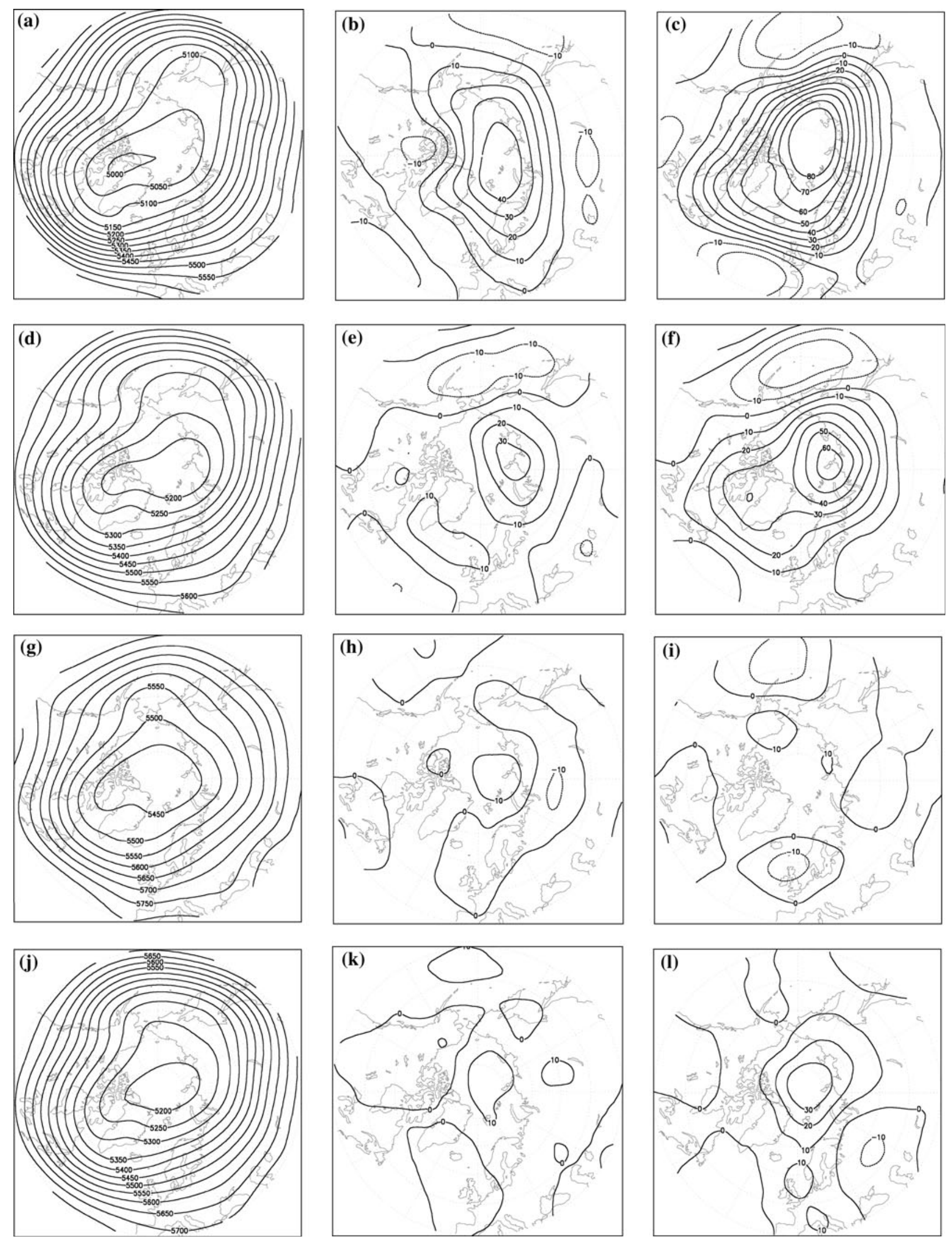
Fig. $7500 \mathrm{hPa}$ geopotential height [m] over the Arctic and the Northern mid-latitudes as climatological seasonal means for winter 1960-2000 from a reference experiment, b difference in $500 \mathrm{hPa}$ geopotential height $[\mathrm{m}]$ ice-reduced minus reference experiment for winter 1960-2000, c difference in $500 \mathrm{hPa}$ geopotential height [m] ice-free minus reference experiment for winter 1960-2000. d-f same as a-c but for spring 1960-2000, $\mathbf{g - i}$ for summer 1960-2000 and $\mathbf{j}-\mathbf{l}$ for autumn 1960-2000

daily mean $2 \mathrm{~m}$ temperature are simulated especially in the IR simulation which could be due to a higher frequency of advection of continental air masses in a decreased mean westerly flow.

Less winter precipitation is simulated in sub-Arctic regions such as the north-east Atlantic, parts of Central and Eastern Europe and Alaska as well as the Bering Sea (Fig. 10). Here the strongly enhanced sensible and latent heat fluxes over the Arctic (Table 4; Fig. 5b, c) lead to vertical
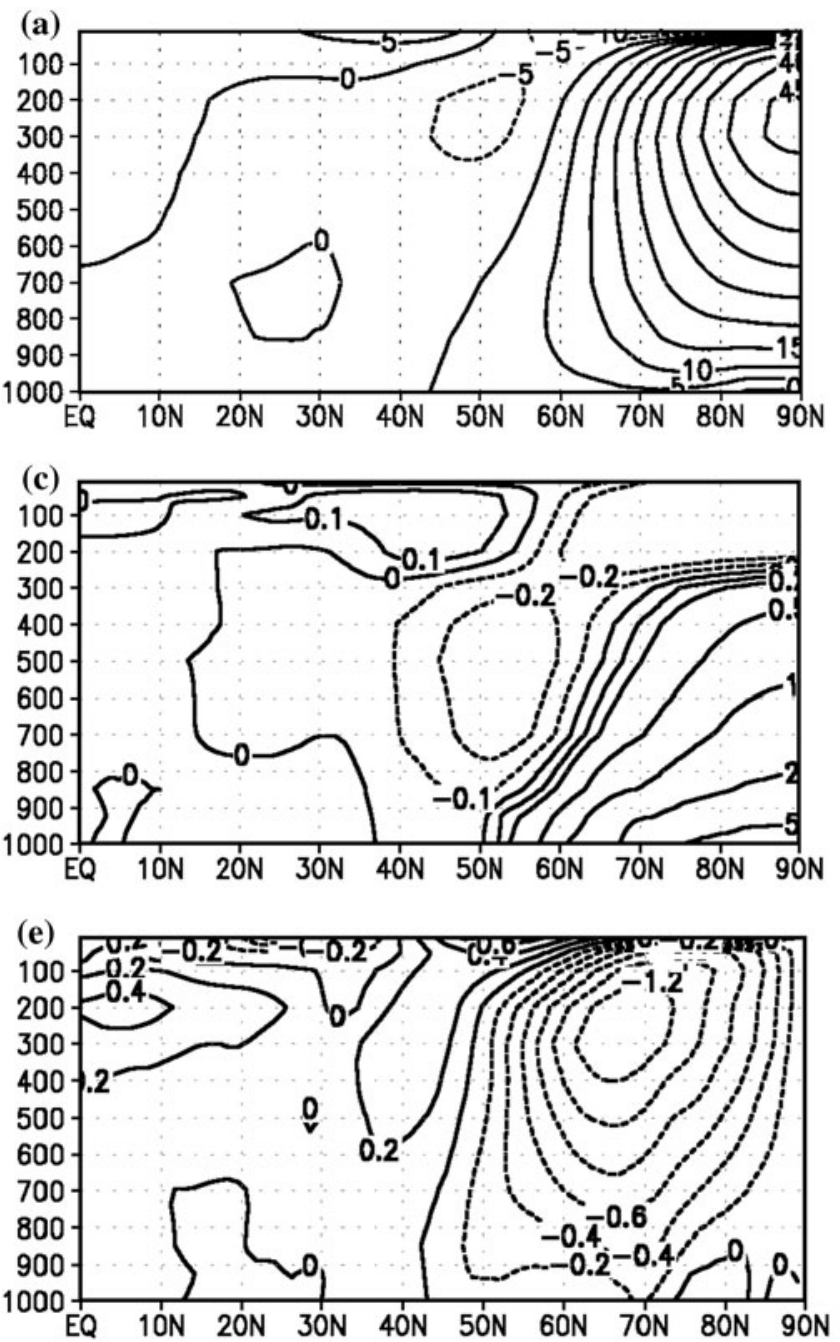

Fig. 8 Zonally averaged cross sections of differences in geopotential height $[\mathrm{m}]$ for $\mathbf{a}$ ice-reduced minus reference experiment and $\mathbf{b}$ icefree minus reference experiment as climatological means for winter 1960-2000. c, d same as a, b but for temperature $\left[{ }^{\circ} \mathrm{C}\right], \mathbf{e}, \mathbf{f}$ same as $\mathbf{a}$, circulation changes towards more upward motion over the Arctic and more downward motion over the surrounding areas and therefore to a regional shift of the precipitation from the sub-Arctic to the Arctic. The strong precipitation decrease over the north-east Atlantic is in addition triggered by less cold air advection and therefore less convection due to the anomalous southerly/south-westerly flow in this area (Fig. 6b, c). In spring the signal of less precipitation is restricted to areas close to the applied forcing. In summer and autumn no clear signal can be seen.

\section{Discussion}

The strong simulated increases in the net surface shortwave radiation in spring and summer in our idealized sensitivity
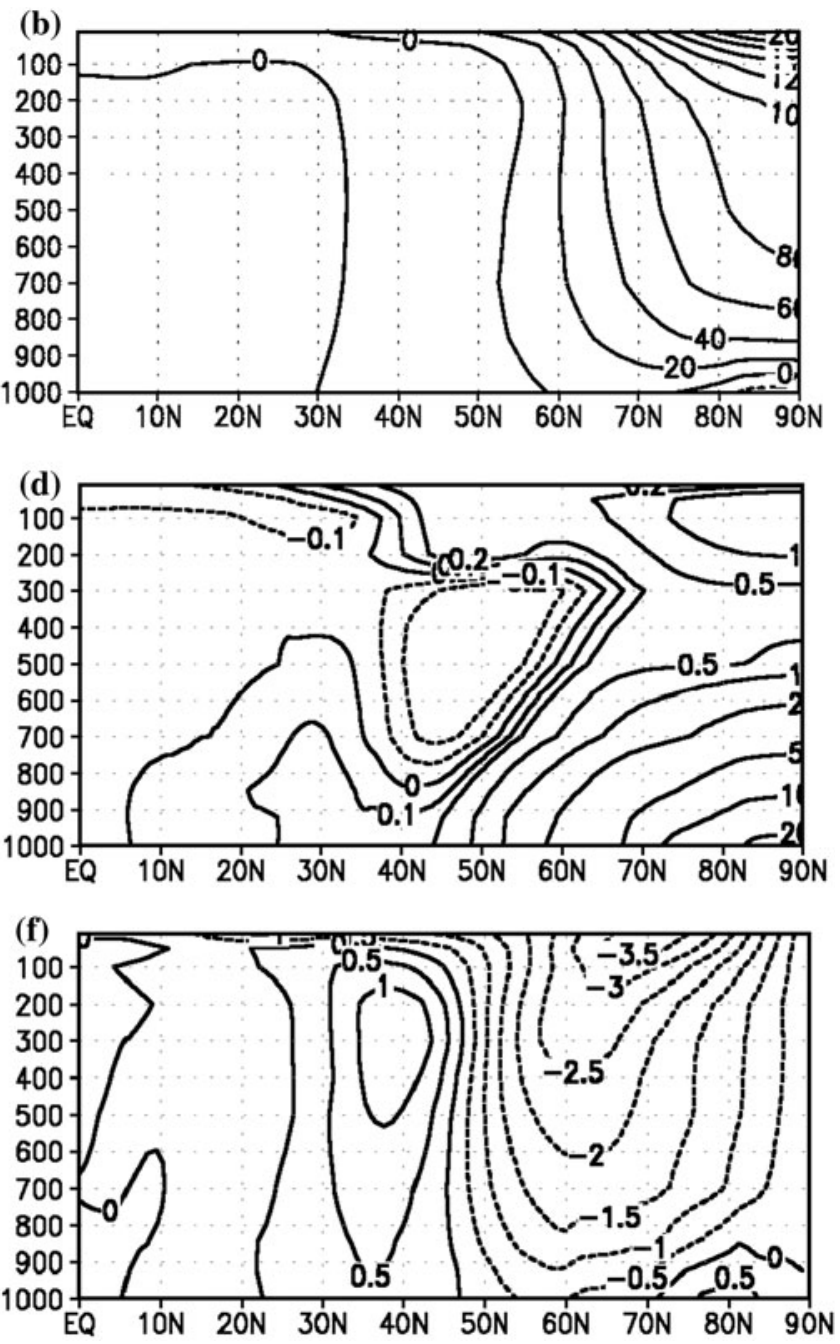

b but for zonal wind $[\mathrm{m} / \mathrm{s}]$. Contour intervals $5 \mathrm{~m}$ in (a), $20 \mathrm{~m}$ in (b), $0.2^{\circ} \mathrm{C}$ in $(\mathbf{e}), 0.5^{\circ} \mathrm{C}$ in (f). Contour lines in $\mathbf{c}$ and $\mathbf{d}$ at $-0.2,-0.1,0$, $0.1,0.2,0.5,1,2,5,10$ and $20 \mathrm{~m} / \mathrm{s}$ 

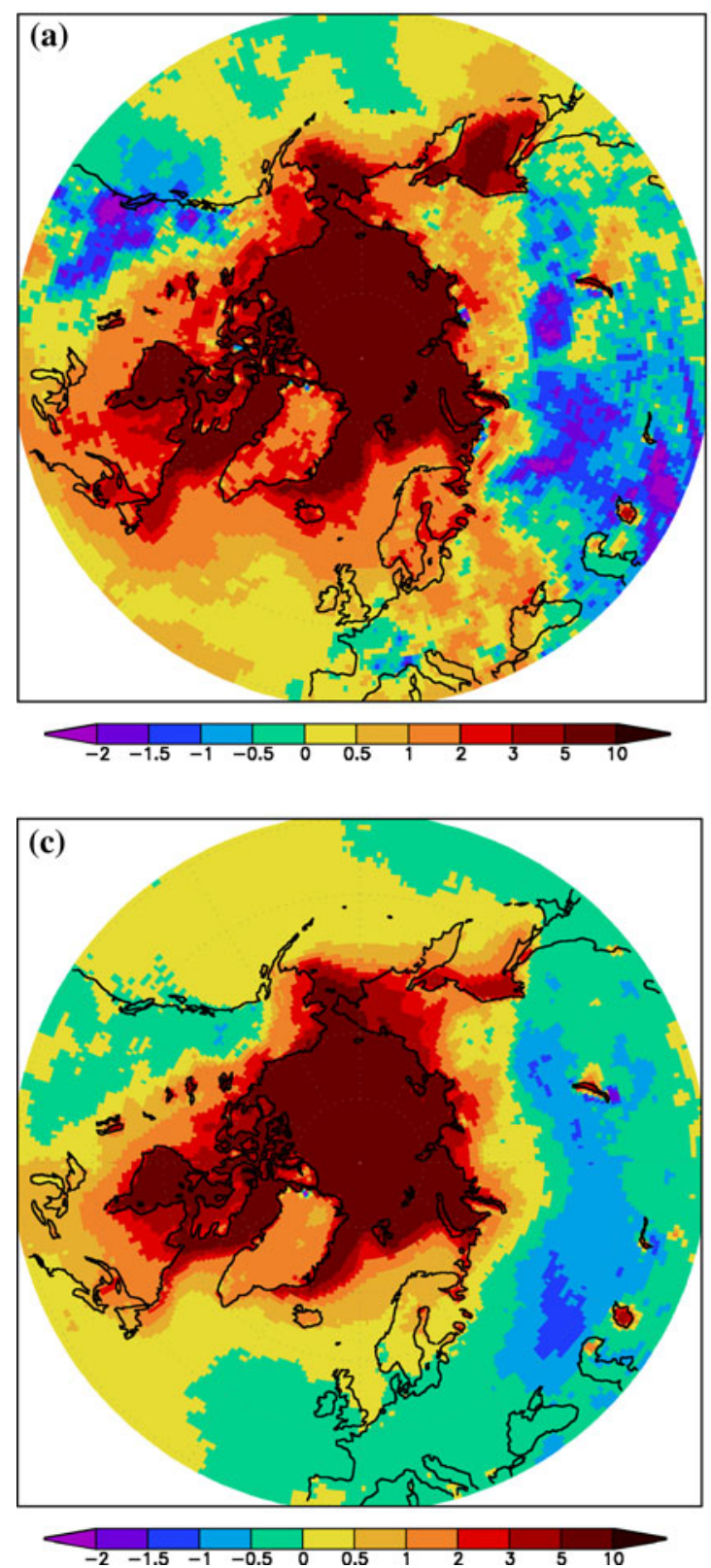
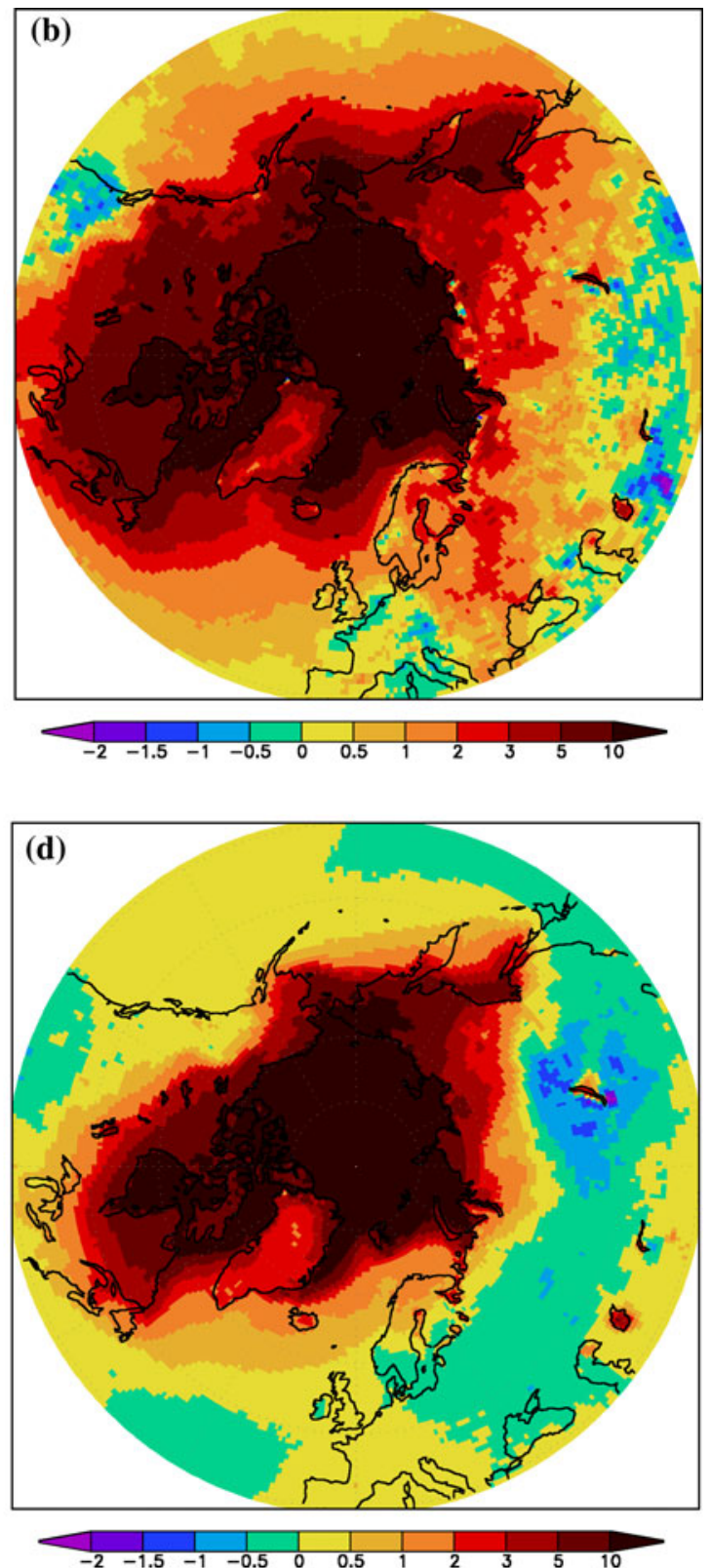

Fig. 9 Difference in 1st percentiles of daily mean $2 \mathrm{~m}$ temperature $\left[{ }^{\circ} \mathrm{C}\right]$ in winter $1960-2000$ over the Arctic and the Northern mid-latitudes $\mathbf{a}$ ice-reduced minus reference experiment and $\mathbf{b}$ ice-free minus reference experiment. c, $\mathbf{d}$ same as $\mathbf{a}, \mathbf{b}$ but for 50 th percentiles

experiments caused by the loss or strong reduction of Arctic sea ice combined with a reduction in cloud cover are comparable with anomalies in summers 2007 and 2008 in ice-free areas which are normally ice covered (Kay et al. 2008; Balmaseda et al. 2010). However, they are quite different from simulated changes in IPCC (2007) coupled model simulations for the end of this century compared to the end of last century. In those simulations an increase in cloud cover limits the increase of the net surface shortwave radiation to $3.7 \mathrm{~W} / \mathrm{m}^{2}$ in spring and $7.5 \mathrm{~W} / \mathrm{m}^{2}$ in summer in the ensemble mean (Sorteberg et al. 2007).
According to the coupled simulations in Sorteberg et al. (2007) the net longwave radiation only becomes slightly more negative in winter and more positive in the other seasons. Again, different changes in the cloud cover might be responsible: decrease in our sensitivity experiments as opposed to increase in the coupled simulations. It should be noted that cloud cover in the Arctic is subject to large uncertainty leading to large uncertainty in the surface energy budget and in future climate predictions. The net surface shortwave flux differs by up to $44 \mathrm{~W} / \mathrm{m}^{2}$ in June averaged over the ocean area north of $70^{\circ} \mathrm{N}$ if comparing 

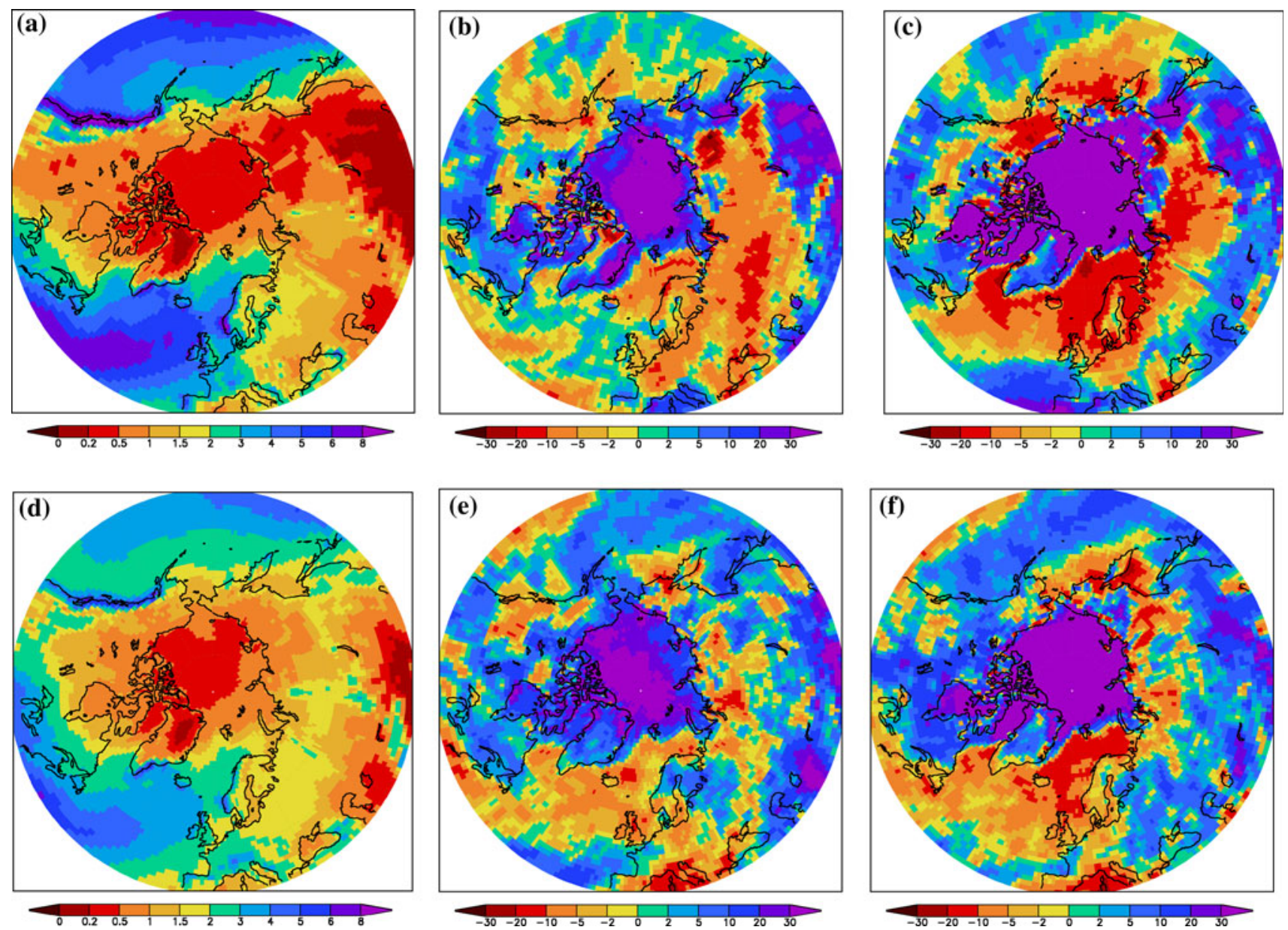

Fig. 10 Precipitation [mm/day] over the Arctic and the Northern mid-latitudes as climatological seasonal means for winter 1960-2000 from a reference experiment, b precipitation change [\%] ice-reduced versus reference experiment for winter 1960-2000, c precipitation change [\%] ice-free versus reference experiment for winter 1960-2000. d-f same as a-c but for spring three IPCC-AR4 models for the time period 1959-1998 (Gorodetskaya et al. 2008). Furthermore, over the past 30 years trends in total cloud cover over the Arctic are not clearly determined (Eastman and Warren 2010).

Our simulated changes in the surface sensible and latent heat fluxes in the IF experiment in winter are almost the same as in Royer et al. (1990). As expected, changes are smaller in the coupled simulations in Sorteberg et al. (2007) at the end of this century compared to the end of the previous century. Common between our study and Sorteberg et al. (2007) are the weaker upward directed latent heat fluxes in summer.

The simulated changes in the annually averaged surface energy budget $\left(+7 \mathrm{~W} / \mathrm{m}^{2}\right.$ in the IR experiment and $-8 \mathrm{~W} /$ $\mathrm{m}^{2}$ in the IF experiment) are substantial as an increase in the annually averaged surface budget by $1 \mathrm{~W} / \mathrm{m}^{2}$ corresponds to a sea ice loss of $0.1 \mathrm{~m} /$ year according to Serreze et al. (2007b). Looking at the ocean, the increased energy transfer from the warmer ice surface into the atmosphere in winter which comes from the addition of energy to the system through the surface forcing is even overcompensated by the stronger energy absorption of solar radiation in summer in the IR experiment. It can not be concluded that the sea ice cover would even further decrease in a coupled experiment with reduced sea ice cover as the ocean heat transport across $70^{\circ} \mathrm{N}$ might change. Regarding the IF experiment, without any strong greenhouse gas forcing seasonal sea ice cover would develop quickly if initializing a coupled simulation without sea ice in winter.

It is noteworthy that at the TOA the loss of energy decreases by about $10 \mathrm{~W} / \mathrm{m}^{2}$ in both sensitivity experiments averaged over the year. This means that the energy gain through the increased net shortwave radiation in spring and summer due to the planetary albedo decrease is stronger than the increased energy loss through longwave radiation in autumn and winter.

While for the net TOA longwave radiation our result from the IF experiment for winter is the same as in Royer 
et al. (1990), they simulate a change of $33 \mathrm{~W} / \mathrm{m}^{2}$ towards more negative values in the net surface longwave radiation while we only simulate $23 \mathrm{~W} / \mathrm{m}^{2}$. A reason could be the weaker decrease in cloud cover in our IF simulation in winter by $8 \%$ compared to Royer et al. (1990) who simulate a decrease by $10-15 \%$. Consistently the general circulation response in our IF experiment is generally similar compared to Royer et al. (1990), but less pronounced. Furthermore, general circulation responses are comparable to Seierstad and Bader (2009) and Singarayer et al. (2006). Our results are also consistent with observed $1000-500 \mathrm{hPa}$ thickness increases in areas of sea ice loss and surface temperature increases as found by Overland and Wang (2010).

Vertical mixing seems to be more efficient in our IF experiment compared to the similar experiment in Royer et al. (1990) in which temperature increases are only simulated below $600 \mathrm{hPa}$ in the Arctic. Similar to Royer et al. (1990) is the adiabatic cooling anomaly in the midtroposphere in $40-50^{\circ} \mathrm{N}$ which is due to an upward motion anomaly.

Qualitatively, our Arctic near-surface temperature change agrees with the observed change in the recent years in late autumn (Overland and Wang 2010, their Fig. 4) and with the response to increasing greenhouse gas and aerosol concentrations at the end of this century in the ensemble of IPCC-AR4 AOGCM A1B scenario simulations (IPCC 2007, their Figure 10.7). However, in addition the ensemble shows a warming over the tropics by up to $5{ }^{\circ} \mathrm{C}$ in the layer $150-300 \mathrm{hPa}$ implying a different zonal wind response.

In our sensitivity experiments, similar to Singarayer et al. (2006), Seierstad and Bader (2009) and Deser et al. (2010), the most pronounced changes outside the Arctic region occur in winter and early spring when the surface forcing is strongest and the meridional temperature gradient is decreased substantially as a result while changes in the other seasons are only minor. In the summer season a surface warming would occur and has already occurred in the summers 2007 and 2008 (Balmaseda et al. 2010) due to stronger shortwave radiation absorption over open water compared to ice which is not considered in our idealized experiments with fixed surface temperature. Nevertheless, the Arctic surface temperature increase and the meridional surface temperature gradient decrease in summer are predicted to be small compared to winter (IPCC 2007, their Figure 10.9).

\section{Summary and conclusions}

Sensitivity experiments on the influence of Arctic sea ice on the Arctic energy budget and climate as well as on the climate of the Northern mid-latitudes have been carried out with an AGCM. Three 40-year experiments have been performed and evaluated: the reference experiment driven by ERA-40 reanalysis SSTs, sea ice surface temperatures (SISTs) and sea ice concentrations (SICs) for 1960-2000, one sensitivity experiment with reduced SICs and increased SISTs (ice reduced, IR) and one with removed sea ice for the same time period (ice-free, IF). All simulations have been run in a spectral resolution of T255L62 corresponding to $79 \mathrm{~km}$ with 62 vertical layers. The icefree winter experiment by Royer et al. (1990) is revisited and extended over all seasons and over a long time period. The sensitivity experiments are idealized experiments and should not be mistaken as predictions for future climate. They are motivated by the recent strong Arctic ice loss which exceeds predicted ice loss from climate models. They contribute to the understanding of the sole influence of ice loss on the Arctic and sub-Arctic climate.

The simulated Arctic energy budget for observed SSTs, SISTs and SICs in our reference experiment is in the range of previous observation and simulation studies. For the sensitivity experiments, substantial changes are simulated all year round. In spring and summer top of atmosphere (TOA) and surface net shortwave radiation are strongly increased by more than $30 \mathrm{~W} / \mathrm{m}^{2}$ in the case of a complete loss of sea ice, which for summer is the case in both IR and IF experiments and in spring in the IF experiment. Both in our sensitivity experiments and in 2007, the year with minimum ice extent in the past 30 years or more, net surface shortwave radiation increases are not only due to the reduced surface albedo but are amplified by a reduction of cloud cover and/or a reduction of the cloud liquid water content. Arctic cloud observations and simulations are subject to large uncertainty and the future sea ice development is very dependent on future trends in Arctic cloud cover.

The energy gain in summer and spring due to the decreased planetary albedo is outweighing the increased energy loss through longwave radiation in winter and autumn at the TOA. For the surface (considering also changes in turbulent heat fluxes) the same is true for the IR experiment while the opposite is true for the IF experiment. In the case of future Arctic summer cloud reductions due to circulation changes similar to the year 2007, a seasonally ice-free Arctic could be in equilibrium.

The changes in the energy budget have implications not only on the Arctic surface climate where the strongly increased latent heat fluxes in winter, spring and autumn lead to increased precipitation but also on the areas surrounding the Arctic ocean where precipitation is decreased in winter and spring. In summer no major changes in the large-scale circulation and precipitation are simulated while there is an increase in surface temperature in coastal 
areas adjacent to the Arctic Ocean. In winter the circulation cells are weakened due to the reduction in poleward heat transport in the sensitivity experiments, especially the polar cell, implying a weaker jet stream. Due to the warmer Arctic, less extreme cold events are simulated in the Northern mid-latitudes.

Changes simulated in our idealized experiments are different from changes predicted in IPCC-AR4 CGCM future climate simulations which indicate an increase in the westerly flow in mid-latitudes in winter as well as more extreme storms and precipitation events. The complex CGCM predictions consider many other influencing factors such as changes in ocean currents and temperature increases in the tropical upper troposphere which lead to a stronger meridional temperature gradient in the upper troposphere and therefore an intensified westerly flow over the mid-latitudes in winter. Another even more important difference is the simulated reduction in cloud cover and liquid water content which is in contrast to AR4 CGCM predictions. Future trends in cloud cover and liquid water content will largely determine the speed of Arctic sea ice decline. Reliable measurements of cloud cover and liquid water content are therefore required to improve the simulation of these parameters.

Acknowledgments We are grateful to ICHEC, the Irish Centre for High-End Computing (http://www.ichec.ie), for technical support to conduct the numerical experiments. The support of the EC-EARTH community and ECMWF is also acknowledged. Furthermore we appreciate the comments of the anonymous reviewers which have helped to improve the paper.

Open Access This article is distributed under the terms of the Creative Commons Attribution License which permits any use, distribution, and reproduction in any medium, provided the original author(s) and the source are credited.

\section{References}

Balmaseda MA, Ferranti L, Molteni F, Palmer TN (2010) Impact of 2007 and 2008 Arctic ice anomalies on the atmospheric circulation: implications for long-range predictions. Q J R Meteorol Soc 136:1655-1664

Budikova D (2009) Role of Arctic sea ice in global atmospheric circulation: a review. Global Planet Change 68:149-163

Chiang JCH, Bitz CM (2005) Influence of high latitude ice cover on the marine intertropical convergence zone. Clim Dyn 25:477-496

Deser C, Walsh JE, Timlin MS (2000) Arctic sea ice variability in the context of recent atmospheric circulation trends. J Clim 13:617-633

Deser C, Magnusdottir G, Saravanan R, Phillips A (2004) The effects of North Atlantic SST and sea ice anomalies on the winter circulation in CCM3. Part II: direct and indirect components of the response. J Clim 17:877-889

Deser C, Tomas R, Alexander M, Lawrence D (2010) The seasonal atmospheric response to projected Arctic Sea Ice Loss in the Late Twenty-First Century. J Clim 23:333-351
Eastman R, Warren SG (2010) Interannual variations of Arctic cloud types in relation to sea ice. J Clim 23:4216-4232

ECMWF (2006) IFS documentation. Available online at http://www. ecmwf.int/research/ifsdocs/CY31r1/index.html

Gorodetskaya IV, Tremblay L-B, Liepert B, Cane MA, Cullather RI (2008) The influence of cloud and surface properties on the Arctic Ocean shortwave radiation budget in coupled models. J Clim 21:866-882

Hazeleger W, Severijns C, Semmler T, Stefanescu S, Yang S, Wang X, Wyser K, Dutra E, Baldasano JM, Bintanja R, Bougeault P, Caballero R, Ekman AML, Christensen JH, van den Hurk B, Jimenez P, Jones C, Kallberg P, Koenigk T, McGrath R, Miranda P, van Noije T, Parodi JA, Schmith T, Selten F, Storelvmo T, Sterl A, Tapamo H, Vancoppenolle M, Viterbo P, Willen U (2010) EC-earth: a seamless earth-system prediction approach in action. Bull Am Meteor Soc 91:1357-1363

Hazeleger W, Wang X, Severijns C, Ştefănescu S, Bintanja R, Sterl A, Wyser K, Semmler T, Yang S, van den Hurk B, van Noije T, van der Linden E, van der Wiel K (2011) EC-Earth V2: description and validation of a new seamless Earth system prediction model. Clim Dyn (this issue)

IPCC (2007) Climate change 2007. The physical science basis. In: Solomon S, Qin D, Manning M, Chen Z, Marquis M, Averyt KB, Tignor M, Miller HL (eds) Contribution of Working Group I to the Fourth Assessment Report on the Intergovernmental Panel on Climate Change. Cambridge University Press, Cambridge

Kay JE, L'Ecuyer T, Gettelman A, Stephens G, O'Dell C (2008) The contribution of cloud and radiation anomalies to the 2007 Arctic sea ice extent minimum. Geophys Res Lett 35:L08503. doi: 10.1029/2008GL033451

Lindsay RW, Zhang J, Schweiger A, Steele M, Stern H (2009) Arctic Sea Ice Retreat in 2007 Follows Thinning Trend. J Clim 22:165-176

Magnusdottir G, Deser C, Saravanan R (2004) The effects of North Atlantic SST and sea ice anomalies on the winter circulation in CCM3. Part I: Main features and storm track characteristics of the response. J Clim 17:857-876

Nakamura N, Oort AH (1988) Atmospheric heat budget of the polar regions. J Geophys Res 93:9510-9524

Overland JE, Wang M (2010) Large-scale atmospheric circulation changes are associated with the recent loss of Arctic sea-ice. Tellus 62A:1-9

Porter DF, Cassano JJ, Serreze MC, Kindig DN (2010) New estimates of the large-scale Arctic atmospheric energy budget. J Geophys Res 115:D08108. doi:10.1029/2009JD012653

Rayner NA (2002) HadISST1 and the Reynolds et al. analysis. ECMWF ERA-40 Project Series, No. 3, pp 169-176. European Centre for Medium-Range Weather Forecasts, Shinfield, Reading, UK (available online from http://www.ecmwf.int/ publications)

Rayner NA, Parker DE, Horton EB, Folland CK, Alexander LV, Rowell DP, Kent EC, Kaplan A (2003) Global analyses of sea surface temperature, sea ice and night marine air temperature since the late nineteenth century. J Geophys Res 108:4407

Reynolds RW, Rayner NA, Smith TM, Stokes DC, Wang W (2002) An improved in situ and satellite SST analysis for climate. J Clim 15:1609-1625

Royer JF, Planton S, Déqué M (1990) A sensitivity experiment for the removal of Arctic sea ice with the French spectral general circulation model. Clim Dyn 5:1-17

Seager R, Kushnir Y, Visbeck M, Naik N, Miller J, Krahmann G, Cullen H (2000) Causes of Atlantic Ocean climate variability between 1958 and 1998. J Clim 13:2845-2862

Seierstad IA, Bader J (2009) Impact of a projected future Arctic Sea Ice reduction on extratropical storminess and the NAO. Clim Dyn 33:937-943 
Semmler T, Jacob D, Schlünzen KH, Podzun R (2005) The water and energy budget of the Arctic atmosphere. J Clim 18:2515-2530

Serreze MC, Barry RG (2005) The Arctic climate system. Cambridge Atmospheric and Space Science Series. Cambridge University Press, Cambridge

Serreze MC, Holland MM, Stroeve J (2007a) Perspectives on the Arctic's shrinking sea ice cover. Science 315:1533-1536

Serreze MC, Barrett AP, Slater AG, Steele M, Zhang J, Trenberth KE (2007b) The large-scale energy budget of the Arctic. J Geophys Res 112:D11122

Singarayer JS, Bamber JL, Valdes PJ (2006) Twenty-first-century climate impacts from a declining Arctic Sea Ice Cover. J Clim 19:1109-1125
Sorteberg A, Kattsov V, Walsh JE, Pavlova T (2007) The Arctic surface energy budget as simulated with IPCC AR4 AOGCMs. Clim Dyn 29:131-156

Stroeve J, Holland MM, Meier W, Scambos T, Serreze M (2007) Arctic sea ice decline: faster than forecast? Geophys Res Lett 34:L09501. doi:10.1029/2007GL029703

Winton M (2008) Sea ice-albedo feedback and nonlinear Arctic climate change. Arctic Sea Ice Decline. American Geophysical Union, Washington, DC, pp 111-131 